NBER WORKING PAPER SERIES

THE EFFECTS OF FISCAL POLICY ON INTERNATIONAL IMBALANCES:

JAPAN AND THE UNITED STATES

John F. Helliwell

Working Paper No. 2650

\author{
NATIONAL BUREAU OF ECONOMIC RESEARCH \\ 1050 Massachusetts Avenue \\ Cambridge, MA 02138 \\ July 1988
}

\begin{abstract}
Department of Economics, University of British Columbia, Research Associate, National Bureau of Economic Research, and Clifford Clark Visiting Economist, Department of Finance, Ottawa. This paper was prepared for the Japanese Economic Planning Agency Symposium in Tokyo, March 15-17, 1988. It was also part of the research program of the working group in international macroeconomics, based in the Department of Finance. I am grateful to the members of that group for extensive advice and assistance, especially Grant Macpherson for assistance in preparing and analyzing data. In revising the paper, I have benefitted from the helpful comments of many symposium participants, especially Ralph Bryant, Gerry Holtham, Paul Masson, Larry Summers, and Masaru Yoshitomi. This research is part of NBER's research program in International studies. Any opinions expressed are those of the author not those of the National Bureau of Economic Research.
\end{abstract}


NBER Working Paper \#2650

July 1988

\title{
THE EFFECTS OF FISCAL POLICY ON INTERNATIONAL IMBALANCES: JAPAN AND THE UNITED STATES
}

\begin{abstract}
Evidence from three multicountry models is used to assess the currentaccount effects of U.S. and Japanese fiscal policies. Asymetries in the effects of U.S. and Japanese policies are analyzed in some detail, and attributed to differences in country size, in trade patterns (which have only a small effect) and in the extent to which induced changes in real exchange rates switch demand from domestic to foreign output. Fiscal policy has substantial current account effects in the models. For example, switching $\$ 50$ billion of sustained government spending from the United States to Japan would, in the third year, improve the U.S. current account by $\$ 24$ billion and worsen that of Japan by $\$ 20$ billion. Induced changes in nominal exchange rates are found to play a relatively small role in determining the effects of fiscal policy on the nominal current account.
\end{abstract}

John F. Helliwell

Department of Economics University of British Columbia

Vancouver BC, Canada V6T 192 
The Effects of Fiscal Policy on International Imbalances:

Japan and the United States

\section{Introduction}

To what extent do the current account imbalances among the major industrial countries, the Asian NICs and the heavily indebted countries of South and North America represent the inevitable counterparts of fiscal imbalances? To what extent are these imbalances likely to respond to changes in fiscal policies in the major industrial countries? To what extent are exchange rate changes a necessary part of translating changes in fiscal policy into changes in external balances? These are three of the key issues facing domestic and international macroeconomic policy. This paper attempts to address these issues by using evidence from three major multicountry models to explain the effects that fiscal policies in Japan and the United States have on their own current account balances as well as on the current balance of the other country.

There has already been a substantial amount of quantitative research on the linkages between fiscal policies and the current account of the United States. Most of the existing multinational models were involved in a comparative exercise in 1985, in which one of the major experiments involved comparing the international effects of fiscal policies in the United States and in the rest of the OECD (ROECD). ${ }^{1}$ The sources of the U.S. current account deficit, including the roles of divergent fiscal policies in the United States and the

1 The results are presented in full in Bryant, Henderson, Holtham, Hooper, and Symansky, eds. (1988), and shown briefly in section 2 of this paper. 
rest of the OECD, treated as a single unit, were the subject of a workshop at the Brookings Institution in January 1987, based on results from a number of major multicountry models. ${ }^{2}$

The EPA symposium extends the earlier work in a number of respects: the research is symmetric in its consideration of the Japanese and United States current accounts, the perspective is forward-looking, and the structure of the Japanese economy is being studied in some detail, both on its own and in comparison with other countries. In addition, more attention is paid to the effects of each country's policies on the other country's current account, and to the explanation of any asymmetries that may appear when the effects of Japanese and U.S. policies are compared. Three multicountry models were used to prepare evidence for the seminar: those of the Japanese Economic Planning Agency (the EPA World Model, referred to here as EPA), the U.S. Federal Reserve Board (the MultiCountry Model, refersed to here as MCM), and the OECD (the INTERLINK model, referred to here as OECD).

This paper deals principally with the current account effects of fiscal policies, based on simulation experiments run over a six year horizon extending from 1987 through 1992. The figures drawn for this paper show results over the whole six years, while the analytical tables explaining the current account effects in more detail concentrate on the first-year and third-year results of the changes in fiscal policy. The typical fiscal policy change studied is a

2 The main results, which are presented in Bryant, Holtham and Hooper, eds., (1988) showed (e.g. Helkie and Hooper 1988, p. 48) that divergent fiscal policies in the United States and the rest of the OECD could explain most of the U.S. current account deficit that emerged during the 1980s. 
sustained increase in real government spending equal to $1 \%$ of baseline real GNP. Money supplies are held fixed and exchange rates are flexible in the experiments that are the main focus of this paper. Comparable results under fixed exchange rates will, however, be used to show the role that exchange rate movements play in determining the link between budget deficits and external deficits.

The paper starts with an overview of some of the main features of the new evidence, including comparisons with the results prepared for the earlier Brookings conference. The analysis then turns to a more intensive examination of the reasons for some of these results. This is done in two sections, section 3 dealing with the reasons for some of the asymmetries in the current-account effects of Japanese and U.S. fiscal policies, and section 4 briefly analyzing the role of exchange rate movements in establishing the relationship between fiscal policies and international imbalances. The final section then summarizes the results and draws some implications for the analysis of fiscal policy.

\section{Overview of the Evidence}

To provide a basis for comparison. Figure 1 summarizes the average macroeconomic effects of U.S. and ROECD fiscal expansion, as represented by the multicountry models drawn together for the 1985 Brookings experiments. ${ }^{3}$ The

3 The results were put in comparable form in October 1985, in preparation for a conference held in March 1986. The average results shown in figure 1, and in the bottom panels of figure 2, are taken from Table $B$ (p. 52) and Table $G$ (p. 113) of Part Two of Bryant, Henderson, Holtham, Hooper, and Symansky, eds., (1988). The signs of the results of the U.S. fiscal policy have been changed to make it a fiscal expansion, for easier comparison with the ROECD results, and with the results prepared for the EPA Symposium, all of which refer to fiscal 
bottom panels of Figure 2 then show the average U.S. current account effects, from the same experiments, of U.S. fiscal expansion. ${ }^{4}$ The top panels of figure 2 show the U.S. current account effects separately for each of the three models (EPA, MCM, and OECD) involved in the EPA Symposium. By showing comparable results for the 1985 and 1988 experiments, these figures are especially useful in revealing any major changes in model structure between the two sets of experiments. The bottom right two panels of figure 3 compare the 1985 and 1988 results, from the same three models, for the effects of U.S. fiscal policy on the Japanese current balance.

What are the mair features of the 1985 results? In terms of the first-year international transmission of income in response to fiscal policies, the top panels of figure 1 show almost complete symmetry between U.S. and ROECD fiscal policies, with each region's fiscal expansion raising real GNP at home by $1.25 \%$, in response to a fiscal expansion equal to $1 \%$ of GNP, with real GNP in the other region rising by $0.25 \%$. This apparent symmetry is actually the net result of three asymmetries, however, as the larger size of the ROECD, which would tend to make the transmission larger from the ROECD to the United States than vice versa, is offset by the net effect of two other factors. These are the higher propensity to import in the ROECD ${ }^{5}$ and the fact that $50 \%$ of U.S. imports come from the ROECD, while only $12 \%$ of ROECD imports come from the

expansions.

4 Comparable results for Japanese fiscal expansion are not available from the 1985 experiments.

51985 imports were 9\% of GNP for the United States, compared to $20 \%$ for the ROECD. This factor, which would tend to make the transmission relatively smaller from the United States to the ROECD, is more than offset by the difference in trade patterns described in the text. 
United States.

This initial equality of transmission soon disappears, however, as the domestic income effects of the U.S. fiscal expansion are crowded out by the higher prices, exchange rates (except for OECD), and interest rates, and an increasing proportion of the induced income is in the ROECD. By contrast, the ROECD income multiplier remains much higher, with much smaller induced increases in the price level, in the value of the domestic currencies, and in interest rates. The bottom right-hand panel of figure 2 shows the substantial extent to which the US. current account continues to weaken in response to the fiscal expansion, with the average induced current account deficit being about $0.5 \%$ of GNP by the sixth year of the fiscal expansion.

The upper panels of figure 2 show the current account effects of U.S. fiscal expansion on a model-by-model basis for the EPA, MCM and OECD models, with the 1985 and 1988 results compared, expressed both in terms of billion U.S. dollars (on the left-hand side of the page) and as percent of GNP. Looking first at the 1985 results from the three models, the EPA and MCM results show the U.S. current account worsening by more than the average across all twelve models, while the OECD current account effects are smaller than average and show little tendency to grow over the six years.

Comparing the 1985 and 1988 results, it can be seen that the models have changed slightly, so as to move their estimated U.S. current account effects closer to each other, and to the average from the 1985 experiments. Thus alf three models now show the U.S. current account 
consequences growing with time, and to be between $0.5 \%$ and $0.7 \%$ of GNP by the sixth year of the fiscal expansion.

Turning to figure 3 , illustrating the effects of fiscal expansion on the Japanese current balance, the bottom right-hand panels show that in 1985 the EPA model showed by far the largest Japanese effects of U.S. fiscal policy, growing with time to reach almost $2 \%$ of GNP by the sixth year. In the 1988 results, these effects have been cut in half, although they are still somewhat larger than those of the MCM, and twice as high as those of the OECD model. In all three models the effects of U.S. fiscal expansion on the Japanese current balance are as great as on the U.S. current balance, and somewhat higher in the case of EPA, where the effects are measured as a percent of baseline GNP in all cases.

The top half of figure 3 contains the new results showing the Japanese current account effects of Japanese fiscal expansion. These are largest for EPA, but in all three models are less than one half as large as the effects of U.S. fiscal policy, as shown in the bottom half of the figure. All three models show the Japanese fiscal expansion to worsen the Japanese current account by about 500 billion Yen in the first year, as shown by the top right-hand panel of figure 3. Thereafter, the EPA effects continue to grow, while the MCM effects remain fairly constant and the OECD effects gradually disappear.

As seen by comparing figures 2 and 3 , the three models give very similar estimates of the effects of U.S. fiscal policy on the U.S. current account, but rather different estimates of the effects of Japanese fiscal expansion on the 
Japanese current account. To understand these differences better, we can exploit the fact that the current account is simply the difference between private investment and the sum of gross private saving and net saving of the public sector. Similarly, any worsening in the real current account deficit in response to fiscal stimulus can be expressed equally well as the amount by which induced absorption exceeds induced real output. To make use of these alternative ways of viewing the current account, figure 4 shows the own-country effects of fiscal expansions in terms of real GNP, real absorption, gross private savings and gross private investment. ${ }^{6}$

Looking first at the results for Japan, the EPA model's increases in real absorption and GNP, with real absorption steadily rising to a level $2 \%$ above baseline by the sixth year, show that the growing current account effects shown in figure 3 are not the result of crowding out. but of imports increasing with absorption and income as all three continue to grow. For the other two models, the real GNP and domestic absorption effects are both crowded out; for the MCM some of this crowding out takes the form of increased real imports, but in neither case is there a widening gap between absorption and GNP. Thus in none of the three models is there evidence of the multiplier process being truncated by increasing real import penetration. The panel showing private investment as a share of GNP reveals that the crowding out of domestic absorption that takes place in MCM and OECD is of private investment, which is slightly above

6 The matching results for the induced changes in the government balance as a share of GNP, which reveal the extent to which additional tax revenues serve to finance the increase in government spending (equal to $1 \%$ of GNP), are shown in the second-row panels of figures 5,7 , and 9 , which contain the modelby-model results for EPA, MCM and OECD, respectively. Since the government spending is financed by borrowing, the cumulating debt also increases government spending further through its impact on public debt charges. 
baseline throughout for EPA, but increasingly below baseline for MCM, and especially for OECD.

The situation is quite different in the case of the United States. Here, all the models agree that the current account deficit will continue to grow as a share of baseline GNP, reaching $0.5 \%$ by the sixth year. As shown by figure 4 , however, this agreement about the current account effects is the net result of some offsetting differences. Although all three models show declining real muttipliers for the United States, the first-year multiplier is about 1.75 for MCM compared to about 1.0 for the OECD, with EPA midway between.

Although all three models show steady crowding out of the U.S. GNP effects as time progresses, the MCM multiplier falls much less slowly than the other two, and is still above 1.0 in the sixth year. There is an offsetting difference in the behaviour of real absorption, which is continually falling, relative to its initial increase, in $M C M$ and $O E C D$, while consistently remaining roughly $1.5 \%$ above baseline values for EPA. Higher investment is the key to the sustained absorption in EPA, with investment higher by almost $1 \%$ of GNP by the sixth year. In the other two models, investment is below baseline by increasing amounts, averaging about $0.25 \%$ of GNP over the six year period.

The models also reveal some substantial differences in U.S. private savings behaviour, with savings up by much more than the induced change in GNP in OECD, up only slightly in MCM, and with the EPA falling in between. The EPA estimate of induced private savings (as a \% of GNP) continually rises, thus helping to finance the growing government deficit. 
Figures 5 through 10 broaden the focus to consider both the own-country and the cross-country effects of Japanese and U.S. and fiscal policies on a comparative basis. To do this, there are two figures for each of the three models. The left-hand panels of each figure show the own-country and crosscountry effects of Japanese fiscal expansion, while the right-hand panels do the same for U.S. fiscal expansion. What are the main points of simitarity and difference revealed by these figures?

Important points of similarity include:

- In all three models, U.S. fiscal policy has large and growing effects on the current accounts of both countries, with the effects on Japan being about as large as those on the United States, when measured as percent of GNP.

- In all three models, Japanese fiscal policy initially affects the Japanese current balance by about as much as does the U.S. fiscal expansion (although of course in the opposite direction), while the influence on the U.S. current account is close to zero.

- In all three models, U.S. interest rates rise by substantial amounts that increase as the U.S. fiscal expansion continues. By the sixth year, U.S. Iongterm rates are 150 to 200 basis points higher in nominal terms. Japanese interest rates are pulled up by about one-third as much (less in MCM) in response to the U.S. fiscal expansion. 
- In all three models, U.S. fiscal expansion produces continuing U.S. inflation averaging about $0.5 \%$ annually in each of the models. Thus real longterm interest rates are 100 to 150 basis points higher by the sixth year.

- In all three models. U.S. fiscal expansion produces a substantial change in the U.S. unemployment rate, while Japanese fiscal expansion has almost no impact on the Japanese unemployment rate.

The most striking of these results is the contrast between the very large current account effects of U.S. fiscal expansion and the much smaller effects of Japanese fiscal expansion. This asymmetry has been the subject of much comment, and will be analyzed in some detail in the next section of the paper.

Important differences among the models include:

- Although all three models show the Japanese GNP effects of U.S. fiscal expansion to be greater than the U.S. effects by the sixth year, the difference is much greater for EPA, which shows Japanese GNP up by over $2 \%$ by the fifth year. This appears to reflect a possibly non-convergent real multiplier process in the Japanese block of the EPA model.

- Although none of the models shows large changes in the Japanese price level in response to Japanese fiscal expansion, there are noticeable differences among the models. There is no induced inflation in EPA, despite the much stronger multiplier process in operation in that model. 
By contrast, in response to U.S. fiscal expansion, the EPA model shows substantial Japanese inflation, even more than in the United States over the first two years, while MCM shows about one-third as much inflation as in the United States and the OECD almost none.

- In both EPA and MCM, the U.S. dollar appreciates by about $3 \%$ in nominal terms in response to U.S. fiscal expansion, while the OECD model shows a depreciation of the dollar.

- In real terms, MCM shows the real value of the dollar returning to baseline by the sixth year, while EPA shows a real appreciation of about $4 \%$ and OECD a real appreciation of about $2 \%$.

- The initial depreciation of the dollar in OECD under U.S. fiscal expansion appears to be related primarily to the movement of short-term interest rates outside the United States. In that model, Japanese short-term rates rise almost as much as U.S. rates in response to U.S. fiscal expansion, while the induced changes in Japanese interest rates are much smaller in the other two models. ${ }^{7}$

- All three models show initial appreciation of the yen in response to Japanese fiscal expansion, although by the sixth year the combination of price and exchange rate changes are such that the real value of the yen is up by $2 \%$

7 Viewed in terms of conventional LM and BP curves, a depreciation in response to fiscal expansion arises if the LM curve is flatter than the BP curve. The rise in foreign interest rates can be treated as an upward shift of the BP curve, increasing the chances that the LM and IS curves, after the latter has shifted right in response to fiscal expansion, should intersect below the BP curve, thus indicating incipient depreciation. 
in EPA, and down by $1 \%$ in MCM and OECD.

The most striking of the differences listed above relate to the multiplier process in the EPA model and to the different movements of exchange rates. The latter issue will be addressed further in section 4, which analyzes in more detail the role of exchange rate changes in the transmission of the effects of fiscal policy.

\section{Asymmetries in Current Balance Effects}

This section attempts to spell out in more detail why the models show that U.S. fiscal poticies have much larger effects on the Japanese current account than vice versa. To do this most clearly, it is perhaps helpful to start with the simplest case, where relative prices are initially unchanged and all current account effects are due to increases in real imports of the country undertaking fiscal expansion. In that simple case, the effect of U.S. fiscal expansion on the Japanese current account depends only on the U.S. multiplier, the U.S. marginal propensity to import, and the marginal share of U.S. imports that comes from Japan. A similar relationship, with the names changed, determines the effects of Japanese fiscal expansion on the U.S. current account.

If one compares the Japanese current account effects of U.S. fiscal expansion to the U.S. current account effects of Japanese fiscal expansion, measuring the effects in relation to the second country's GNP, then the relative size of the countries enters in two ways. First, if the fiscal 
expansion is defined in relation to GNP, then the initial increase in spending will be larger if the larger country expands. Second, for given trade ratios and import propensities, any change in real trade flows will be a larger share of the smaller country's GNP. Using purchasing power parity exchange rates 8 . U.S. GNP was about 2.8 times as large as that of Japan in 1987. This would imply that if the two countries had the same propensity to import from each other, and if both countries had the same domestic expenditure multipliers, then U.S. fiscal expansion of $1 \%$ of U.S. GNP would affect the Japanese current account (measured as a \% of Japanese GNP) by about eight times as much $(2.8 \times 2.8=7.84)$ as a Japanese fiscal expansion of $1 \%$ of GNP would affect the U.S. current account, measured as a percent of U:S. GNP.

To take a concrete example, the top right hand panels of figures 5,7 and 9 show that U.S. fiscal expansion improves the Japanese current balance, in the first year, by about $0.25 \%$ of GNP. If the structures of the two economies were identical, in the manner described above, then one would expect to find in the top left panel of the same figures that the U.S. current balance would improve by about $0.03 \% \quad(=0.25 / 7.84)$ of U.S. GNP in response to the Japanese fiscal expansion. On average over the first year, the MCM improvement is about $0.045 \%$, while in EPA and OECD it is substantially less, about $0.01 \%$.

In the rest of this section, we shall take a more systematic look at the nature and the sources of these differences, separating the influences operating through exchange rate changes, second-round trade effects, and trade in services. This will be done by a

8 The PPP exchange rates are from Blades and Roberts (1987). 
series of five lables, each of which builds upon the previous tables.

Table 1 starts by showing the induced real current account effects in the expanding country. The first columns show how induced real imports can be explained as the product of the fiscal multiplier and the marginal propensity to import. Columns 1 and 2 show the multipliers and marginal propensities to import under fixed exchange rates, ${ }^{9}$ and columns 3 and 4 show how these two numbers are altered by the induced changes in exchange rates. The propensities to import are for merchandise only, because of the restricted information available about service imports in real terms. The numbers in column five for induced real merchandise imports are thus equal to the increase in government spending, measured in billion 1980 yen for Japan and in billion 1982 dollars for the United States, times the flexible exchange rate multiplier (from column 3) times the marginal propensity to import (from column 4). ${ }^{10}$ Column 6 shows the column 5 figures as a percent of baseline real GNP, while column 7 reports the change in the real current account balance as a percent of GNP. Column 7 is thus equal to the negative of column 6 plus any induced changes in real merchandise exports and net real exports of services.

Comparing the results for the United States and Japan, we might expect to find fairly similar values in column 6 for the United States and Japan, assuming the same fiscal multipliers, since, as shown at the bottom of the

9 These are obtained from the results of the fiscal expansions run with exogenous exchange rates.

10 The "marginal propensities" reported are not the partial effect of real GNP on real imports, but the total change in real imports divided by the total change in real GNP. The numbers reported in column 5 can thus be obtained directly from the simulation output. 
table, Japan and the United States had about the same average propensities to import in 1987. All three models show induced real imports in the first year to be substantially larger for the United States than for Japan: more than $50 \%$ larger in the case of EPA, twice as large in MCM and more than three times as large in OECD.

The reasons for the larger bulge in U.S. imports differ by model. In the case of EPA, the import propensities are approximately the same in the two countries, and the difference is due entirely to the larger first-year fiscal multiplier in the United States. For MCM, the fiscal multipliers and the marginal propensities are both about $50 \%$ larger for the United States than for Japan. For both EPA and MCM, the differences are larger with flexible than with fixed exchange rates, as would be expected in the light of the greater real appreciation of the dollar ${ }^{11}$ that takes place in those models. For OECD, the difference appears to be entirely due to a much higher U.S. marginal propensity to import goods. This is not due to exchange rate effects, as the U.S. depreciates in nominal terms in that model in response to U.S. fiscal expansion

How do these comparisons change when account is taken of induced real exports of goods, and of net exports of services? For both EPA and MCM, taking these changes into account more than offsets the higher U.S. imports of goods, so that the induced real trade deficit is higher for Japan than for the United States. Before discussing these effects in slightly more detail, we first

11 The comparison being made here is between the appreciation of the dollar under U.S. fiscal expansion and the appreciation of the yen under Japanese fiscal expansion. 
consider tables 2 and 3 , which spell out more systematically the sources of the asymmetries flowing through real merchandise imports.

Table 2 simply restates the induced real imports of goods in terms of the real GNPS of the two countries, to provide raw material for table 3, which shows indices of asymmetry and reveals their sources. The total index shown in column 1 of table 3 is, as discussed before, the ratio of the effects of U.S. fiscal policy (on Japanese merchandise exports to the United States) to the effects of Japanese fiscal expansion (on U.S. merchandise exports to Japan), where the fiscal expansion is $1 \%$ of real GNP and the induced real exports are measured as percent of the exporting country's real GNP. Columns 2 to 5 of table 3 show the components explaining the overall index of asymmetry. The index in column 1 is the product of the sub-indices in columns 2 to 5 , and would take the value of 1.0 if the two countries had exactly the same size and economic structure.

Table 3 shows that the first-year indices of asymmetry range from about 12 . for EPA to 16. for MCM and 23. for OECD, in all cases well above the value of 7.8 that would be accounted for simply by the differences in the sizes of Japan and the United States. For EPA, the additional asymmetry flows mainly from the higher value of the U.S. multiplier. For MCM there is an equally large additional effect from the higher U.S. marginal propensity to import. For OECD, the high asymmetry is entirely due to a marginal propensity to import that is more than three times as high for the United States as for Japan. Trade patterns are not part of the explanation of the observed asymmetry, as the index in column 2 is under 1.0 , reflecting the fact that in 1987 the United 
States obtained $21 \%$ of its merchandise imports from Japan, while Japan obtained $22 \%$ of its merchandise imports from the United States. ${ }^{12}$

Tables 4 and 5 extend the analysis to cover the entire current account in nominal terms, thus including the effects of terms-of-trade changes along with the effects of changes in the volumes of goods and services exports. Table 4 examines the U.S. current balance effects of U.S. and Japanese fiscal expansion, while table 5 shows the effects of the same policies on the Japanese current balance. To remove the asymmetry caused by the different size of the expenditure increase in the two countries, the size of the Japanese fiscal expansion is scaled up in table 4 to be equal to $1 \%$ of U.S. GNP, the same as the fiscal expansion in the United States. This requires the Japanese results to be multiplied by 1.9 , which is the ratio of U.S. to Japanese GNPs in 1987 , when evaluated at average 1987 exchange rates. ${ }^{13}$ Similarly, in table 5 the size of the U.S. fiscal expansion is scaled down to make it equal to $1 \%$ of Japanese GNP. The numbers in table 4 are reported in billion U.S. dollars (at 1982 prices for the real variables), while the results in table 5 are in 100 billion yen (at 1980 prices for the real variables).

The figures in column 5 of table 4 show that, by the end of the third

12 These percentages are based on merchandise trade data for the first three quarters of 1987.

13 The ratio of GNPs at market exchange rates is used to make the fiscal expansion the same size, in terms of U.S. dollars, in both countries, so as to facilitate the comparisons in terms of the changes to current accounts in nominal terms. Since market value of the yen was well above its PPP value in 1987 (almost 50\% above, as reported by Blades and Roberts (1988)), this implies that the real value of the Japanese fiscal expansion is substantially less than in the United States, by roughly the ratio $1.9 / 2.8$. 
year, a $\$ 50$ billion increase in U.S. spending would worsen the U.S. current account by about $\$ 20$ billion (slightly more in MCM), while a similar amount of spending in Japan would improve the U.S. current account by $\$ 4$ to $\$ 5$ billion in MCM and OECD, and about $\$ 2$ billion in EPA.

In the EPA and MCM results, the higher value of the U.S. dollar brought about by fiscal expansion produces terms-of-trade gains (shown in column 2, and included as part of the column 5 figure) averaging about $\$ 3$ billion in the first year. For OECD, with its slight depreciation of the dollar in response to either U.S. or Japanese fiscal expansion, there are terms-of-trade losses to the United States in both cases. EPA and MCM show yen appreciation in response to Japanese fiscal expansion, so they agree with OECD in showing-terms-of-trade losses to the United States in this case.

Table 5 shows the effects of Japanese and scaled-down U.S. fiscal expansion on the Japanese current balance, measured in 100 billion yen. In the first year a fiscal expansion of roughly 35 hundred billion yen worsens the Japanese current account by roughly 5 to 7 hundred billion yen if the fiscal expansion takes place in Japan, or improves the Japanese current balance by 3.5 to 5 hundred billion yen if the fiscal expansion takes place in the United States.

The reasons for the differences between the results in tables 4 and 5 lie in the higher U.S. marginal propensity to import (especially as modelled by OECD) and in the higher U.S. multipliers, initially in EPA and throughout for MCM. As has already been seen, the crowding out of domestic output in the United States increases as time passes, with a larger fraction of the 
additional U.S. spending laking the form of imports. In the way our calculations have been made, this shows up as a higher U.S. marginal propensity to import, which then increases the effects of the U.S. fiscal policy on the Japanese current balance. There is less tendency for this to happen in response to Japanese fiscal policy, so that U.S. fiscal expansion eventually has larger effects on the Japanese current balance than does Japanese policy.

\section{The Role of Exchange Rates}

In discussions about the policies required to remove external imbalances, there are often disagreements about the relative roles to be played by fiscal policies and by exchange rate changes. At one extreme, it is argued, for example, that a reduction in the external value of the U.S. dollar will suffice to restore U.S. current account balance. At the other extreme, it is argued that an exchange rate change is neither necessary nor desirable, and that a drop in the value of the U.S. dollar would induce inflationary effects in the United States and recessionary effects abroad that would remove any positive effects on the balance of payments.

The evidence presented so far in this paper suggests that exchanges rates do move as part of the adjustment to fiscal policy, but their relative importance, either as a part of the translation of fiscal actions to external balances, or as independent instruments, remains to be assessed. This is done in figure 11, which shows how much difference exchange rate movements make to the income and current balance effects of fiscal policy. 
The left-hand side of figure 11 shows the effects on Japan of Japanese fiscal expansion, with the right-hand side doing the same for the United States. The top panels show the exchange rate changes that are triggered by the fiscal expansion. with all fiscal expansions showing appreciations of the local currency except for U.S. fiscal expansion in the OECD model. The next panels show the difference between the fiscal multipliers triggered by these changes in exchange rates, and the bottom two rows show the resulting changes in real net exports and in nominal current balances.

The multiplier results show a difference among the models in the real output effects of exchange rate change. All three models show lower multipliers in response to the appreciations of the yen, and MCM shows a parallel result for the United States. OECD shows the dollar to depreciate, and has a slightly higher multiplier as a consequence. The exception to the pattern is provided by EPA, which shows a higher multiplier (after the second year) in response to the appreciation of the dollar.

The current balance results show that the induced appreciations do tend to contribute to the current account effects of the fiscal policies, but that the contributions are a small part of the total current balance effects shown in earlier figures. Since the induced exchange rate changes vary over time, and among modeis, it is difficult to assess their contributions clearly from figure 11. To provide a clearer picture, figure 12 shows the effects of $10 \%$ exogenous depreciations, first of the yen and then of the dollar.

Figure 12 also compares the results of partial and whole-model simulations 
of exchange rate changes to show the extent to which macroeconomic feedbacks alter the current balance effects of exchange rate changes. The left-hand panels show the effects of a $10 \%$ depreciation on the depreciating country's real net exports and nominal current accounts, based on partial simulations of each model's current account block, while the right-hand panels show the corresponding results from full model simulations. The top half of the page shows the Japanese results of yen depreciation, while the bottom half shows the U.S. effects of dollar depreciation.

For Japan, all of the models show that net exports increase about twice as much in the partial simulations as they do in the full model results. A similar result holds for the nominal current account balance, although here the reduction is rather less for the OECD than for the other models.

For the United States, all of the models show even greater differences between the partial and whole-model results than is the case for Japan. On average, the $10 \%$ depreciation of the dollar improves the current account, in the third year, by $\$ 35$ billion in the partial simulations, compared to $\$ 10$ billion in the full model results. The macroeconomic offsets are greatest in EPA and rather modest in OECD. which shows substantially the largest full-model current balance effects of dollar depreciation.

The general conclusion from the evidence presented in this section is that while exchange rates do tend to move in response to fiscal expansion, these movements are not in themselves a very important part of the current account adjustment process that follows in the wake of changes in fiscal policy. The 
comparisons between the partial and full-model results of exchange rate changes show that the results does not come from small direct effects of exchange rates on trade flows, but from the macroeconomic repercussions that tend to cut absorption in the appreciating countries and increase inflation in the depreciating countries, thus offsetting the effects on the current balance.

\section{Conclusions}

This paper has had a double purpose; to compare the structures of three important multinational models, and to use their evidence, in conjunction with that from other models, to analyze the effects of Japanese and United States fiscal policies on their own and the other country's current balance. This conclusion draws these two strands together by summarizing what the three models have to say about the three questions presented at the beginning of the paper.

The experiments prepared for this symposium did not attempt to estimate the extent to which fiscal imbalances were responsible for international imbalances, although earlier research using these and other multinational models to determine the sources of the U.S. current account deficit suggests 14 that divergent fiscal policies in the United States and the rest of the OECD were responsible for about two-thirds of the increase in the U.S. deficit, with the additional appreciation of the dollar and other factors accounting for the rest. To what extent are these imbalances likely to be reversed by changes in

14 See especially the chapter by Helkie and Hooper in Bryant, Holtham and Hooper, eds. (1988). 
fiscal policies? This paper has considered only changes in the United States and Japan.

Based on the evidence from the three models assessed in this paper, each $\$ 50$ billion reduction in U.S. government spending is estimated to lead, by the third year, to a $\$ 20$

billion reduction in the U.S. external deficit. A similar amount of extra spending in Japan would, by the third year, improve the U.S. current balance by about $\$ 4$ billion. 15 Thus shitting $\$ 50$ billion of spending from the United States to Japan would improve the U.S. current balance by $\$ 24$ billion in the third year, about half of the amount of spending transferred. What about the effects on the Japanese current account?

Increasing Japanese government spending by 3700 billion yen would, in the third year, reduce the Japanese current account surplus by about 700 billion yen. Reducing U.S. spending by the same amount would reduce the Japanese current account surplus by an average of 800 billion yen. ${ }^{16}$ Thus transferring 3700 billion yen of spending ( $1 \%$ of Japanese GNP) from the United States to Japan would reduce the Japanese current account surplus by about 1500 billion

15 These results are from table 4. Relative to the typical results quoted in the text, MCM shows effects of U.S. fiscal policy that are about $25 \%$ larger, and EPA shows effects of Japanese fiscal policy that are about half as great, with a third-year effect on the U.S. current account equal to $\$ 2$ billion for each $\$ 50$ billion spent in Japan.

16 These results are from table 5. There is less unanimity among the models in their estimates of the effects of fiscal policies on the Japanese current balance. All three models suggest, however, that U.S. and Japanese fiscal policies have similar effects on the Japanese current balance. MCM and EPA show rather similar results, while OECD shows effects that are roughly half as big as for the other models. 
yen, or about $40 \%$ of the amount of spending transferred.

Combining this evidence, the models suggest that decreasing U.S. government spending by $\$ 50$ billion, with spending in Japan increased by the same amount, would, in the third year, reduce the U.S. current account deficit by about $\$ 25$ billion and reduce the Japanese external surplus by $\$ 20$ billion.

The models are not uniform in their estimates, but they all agree in finding some asymmetry in the current balance effects of Japanese and U.S. fiscal policies, even after account is taken of the differing sizes and trade patterns of the two countries. The main reason for this lies in the greater crowding out apparent in the U.S. models, and the greater extent to which the crowding out of domestic GNP effects is in favour of imported goods and services. This asymmetry grows with time, so that the third-year results reported above for U.S. fiscal contraction would show less improvement in the U.S. balance of payments if reported for the second year, and more if reported for the fourth and subsequent years. The implication of this for policy is that while there may be substantial linkages from fiscal policies to current balances, they accumulate with time, and cannot be expected to have dramatic effects in the short term. Viewed from the perspective of the early 1980s, the inference is that the differential fiscal stances of the United States and the rest of the OECD might have been anticipated to lead eventually to the current account results of the late 1980 s.

Finally, what about the role of exchange rates in the fiscal transmission process? This was the subject of section 4 , where it was shown that exchange 
rates do tend to move during the adjustment process, generally so as to appreciate the currency of the fiscally expanding country. However, these exchange rate movements do not contribute a very large part of the power of the expenditure switching process. In particular, the comparisons between the partial and the full-model results of exchange rate changes show that macroeconomic repercussions, which tend to reduce absorption and inflation in the appreciating countries and to increase them in the depreciating countries. act to truncate the substantial direct effects of exchange rates on trade flows. ${ }^{17}$

\section{REFERENCES}

Blades, D. and D. Roberts (1987) "A Note on the New OECD Benchmark Purchasing Power Parities for 1985" OECD Economic Studies No. 9: Autumn 1987.

Bryant, R., D. Henderson, G. Holtham, P. Hooper, S. Symansky, eds., (1988) Empirical Macroeconomics for Interdependent Economies.(Washington: Brookings Institution).

Bryant, R., G. Holtham and P. Hooper, eds., (1988) External Deficits and the Dollar: The Pit and the Pendulum. (Washington: Brookings Institution).

Helkie, W.L. and P. Hooper (1988) "The U.S. Deficit in the 1980s: An Empirical Analysis". Chapter Two in Bryant et al, eds. External Deficits and the Dollar: The Pit and the Pendulum.

Helliwell, J.F., J. Cockerline and R. Lafrance (May 1988) "Multicountry Modelling of Financial Markets": Paper prepared for FRB Conference on

17 In his comments on the paper, Gerry Holtham noted that none of the three models surveyed for this conference involve model-consistent expectations of future interest rates and exchange rates, and suggested that consistent expectations, would be likely to increase the exchange-rate effects of fiscal policy. This issue has been addressed in a subsequent paper (Helliwell, Cockerline and Latrance 1988), which compares the results of adaptive and model-consistent expectations in a G7 version of MULTIMOD (Masson et al. 1988 describes the IMF's G3 model on which the G7 version is based.) Over the first three years of U.S. fiscal expansion, the consistent expectations version does show about four times as much dollar appreciation, on average, as the adaptive expectations version, but the current account effects are only about $15 \%$ greater, for the reasons discussed in the text. 
Monetary Aggregates and Financial Sector Behaviour. May 26-27, 1988.

Masson, P., M. Dooley, R. Haas and S. Symansky (1988) "MULTIMOD: A MultiRegion Econometric Model", IMF Working Paper 88-23, (Washington: International Monetary Fund). 


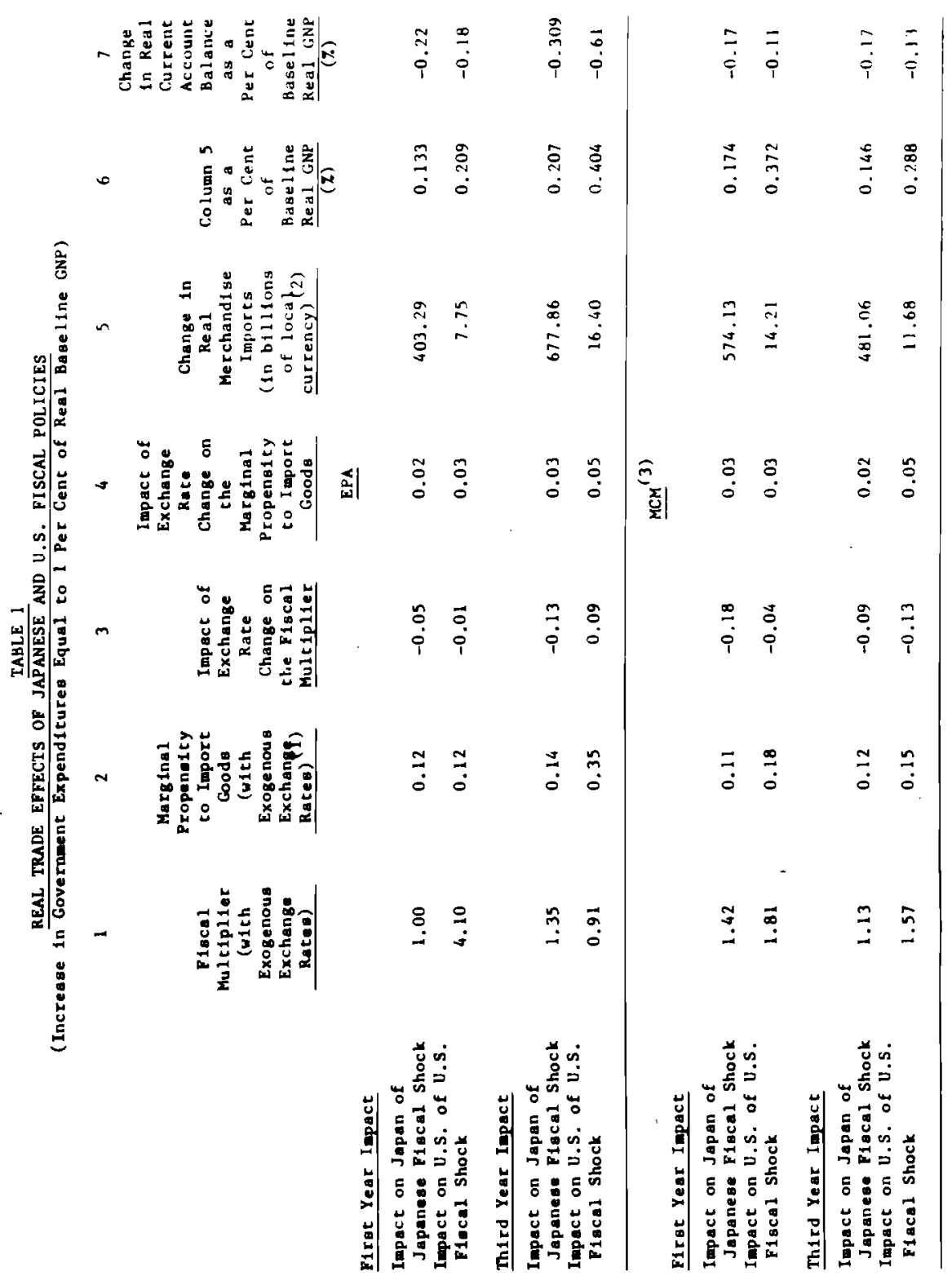




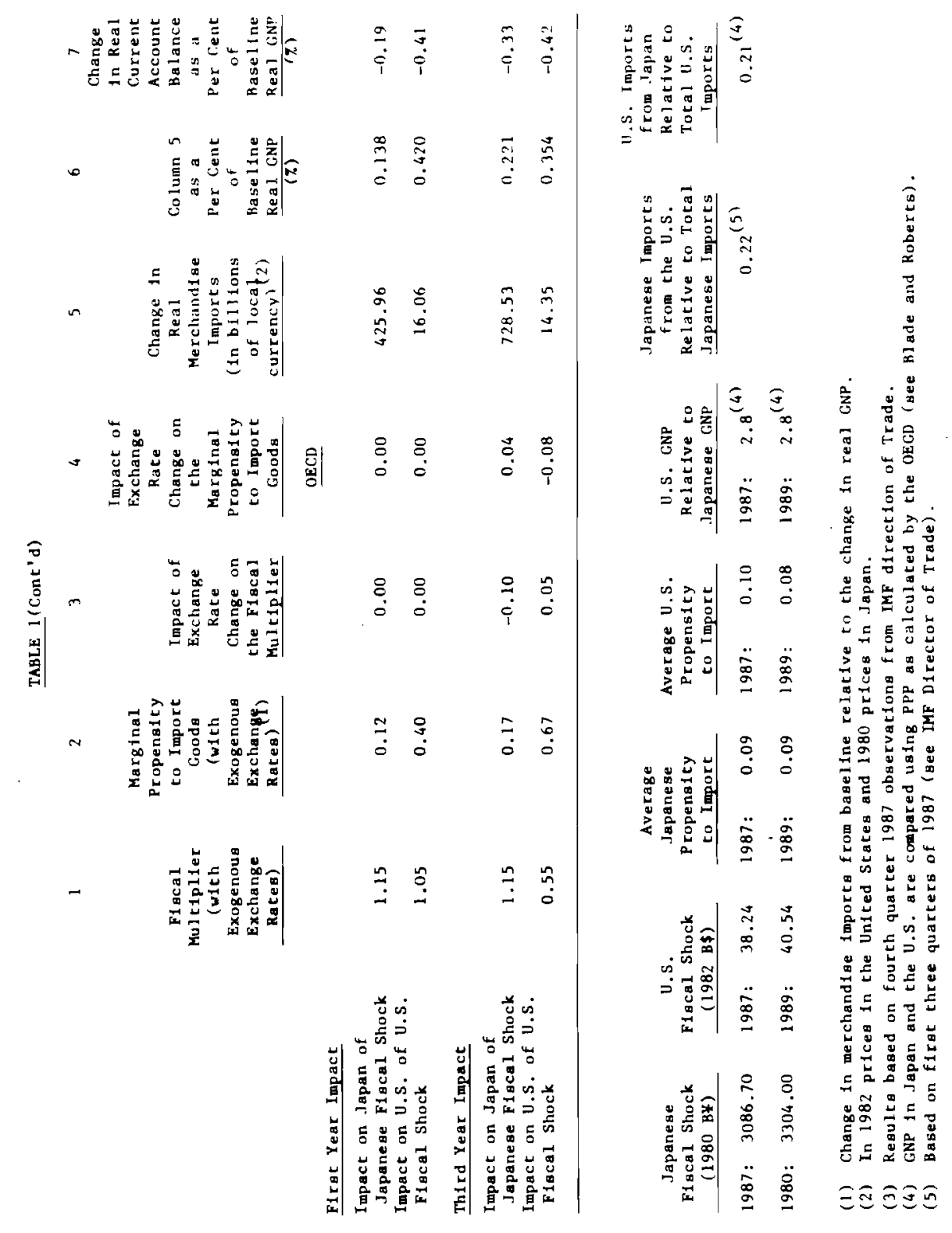




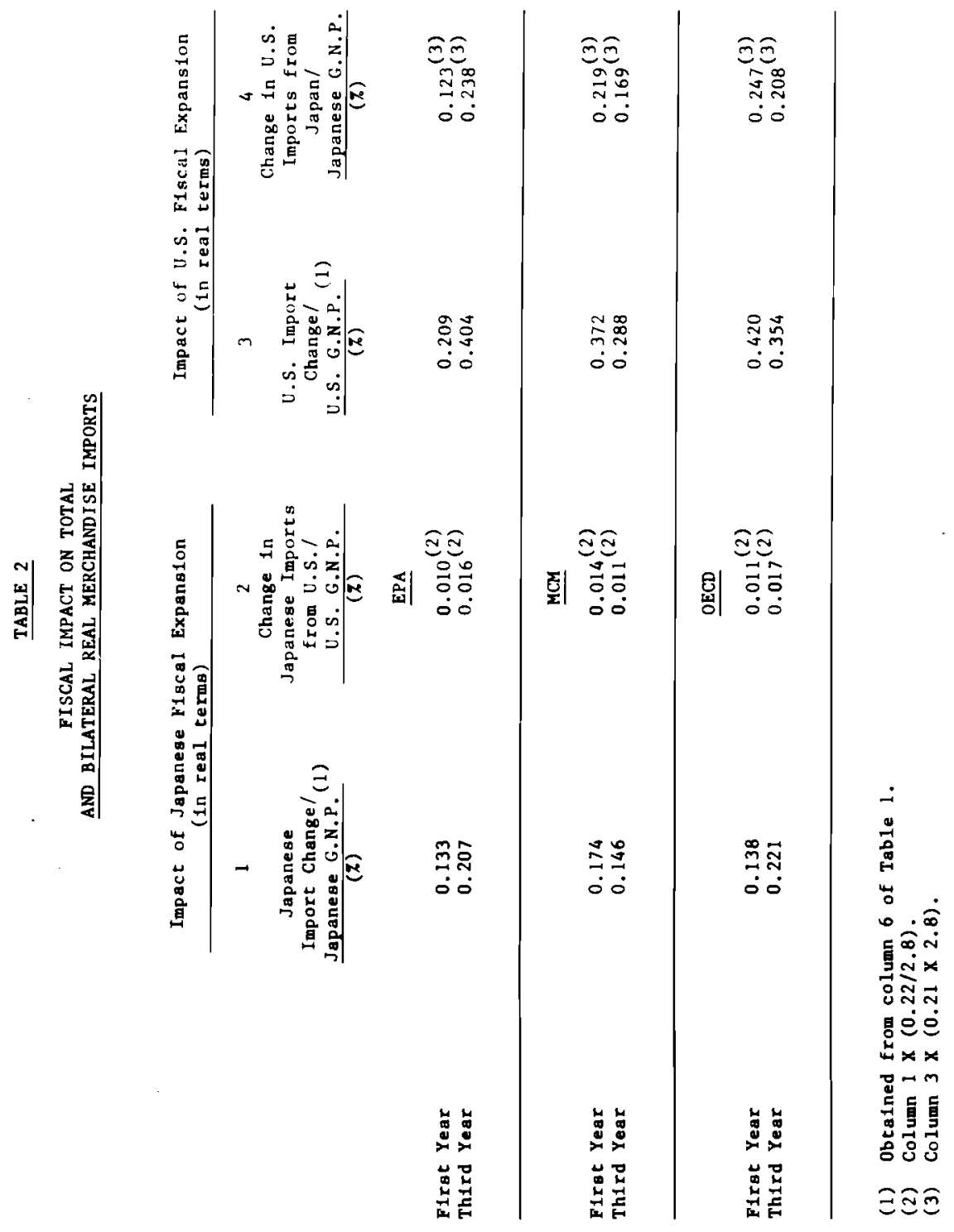




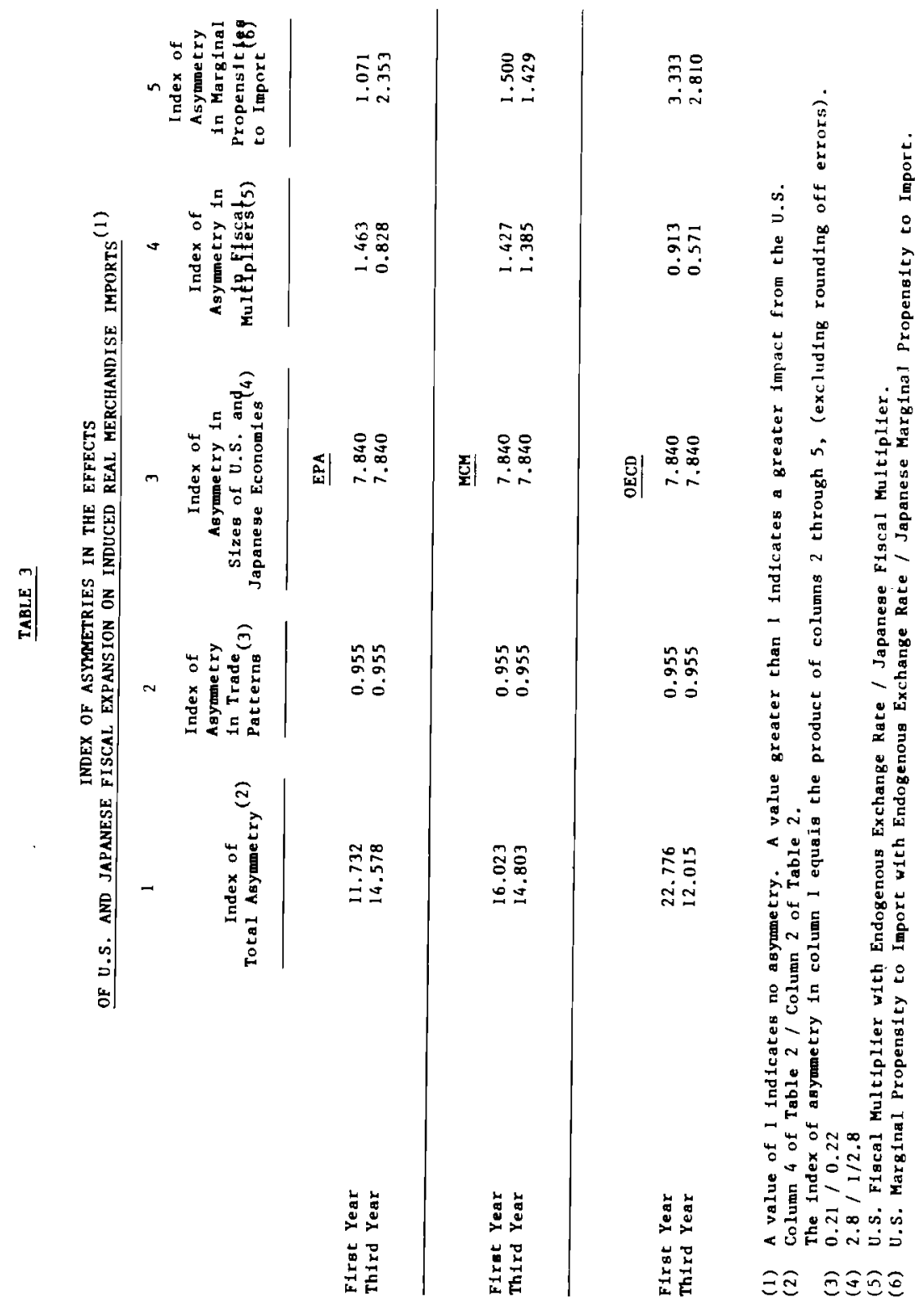




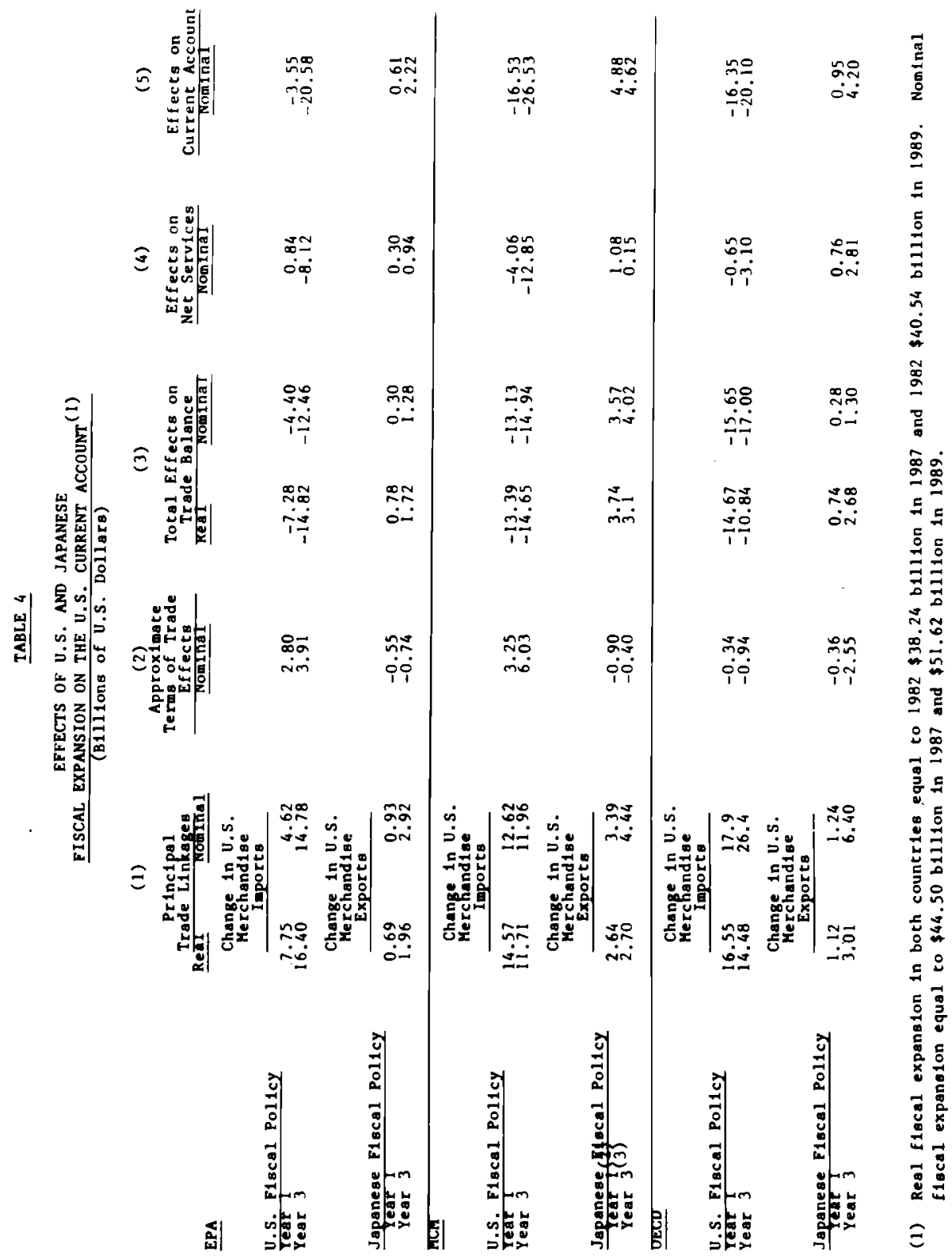




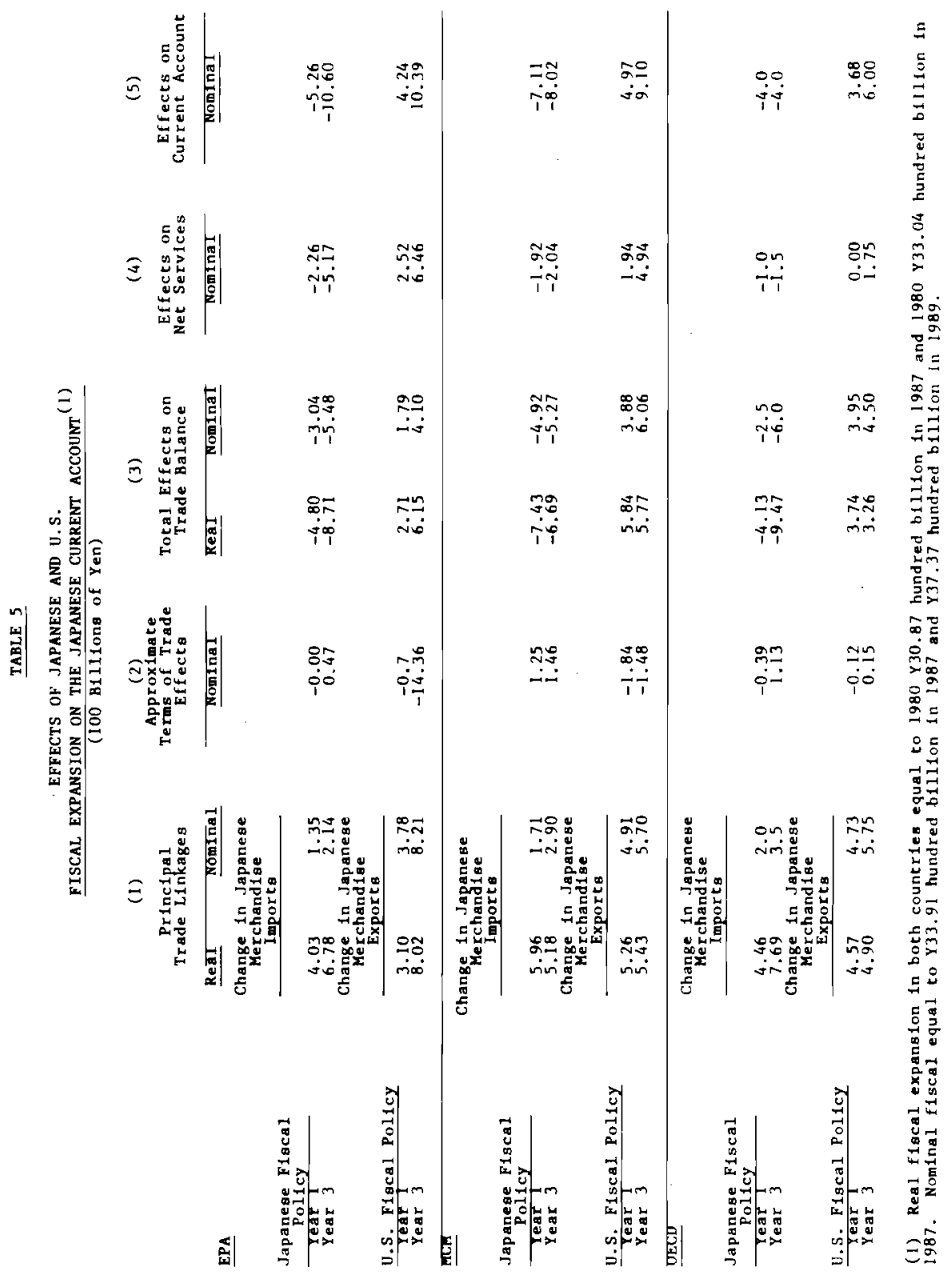




\section{FIGURE I}

hoecd fiscal expansion 1985 RESULTS
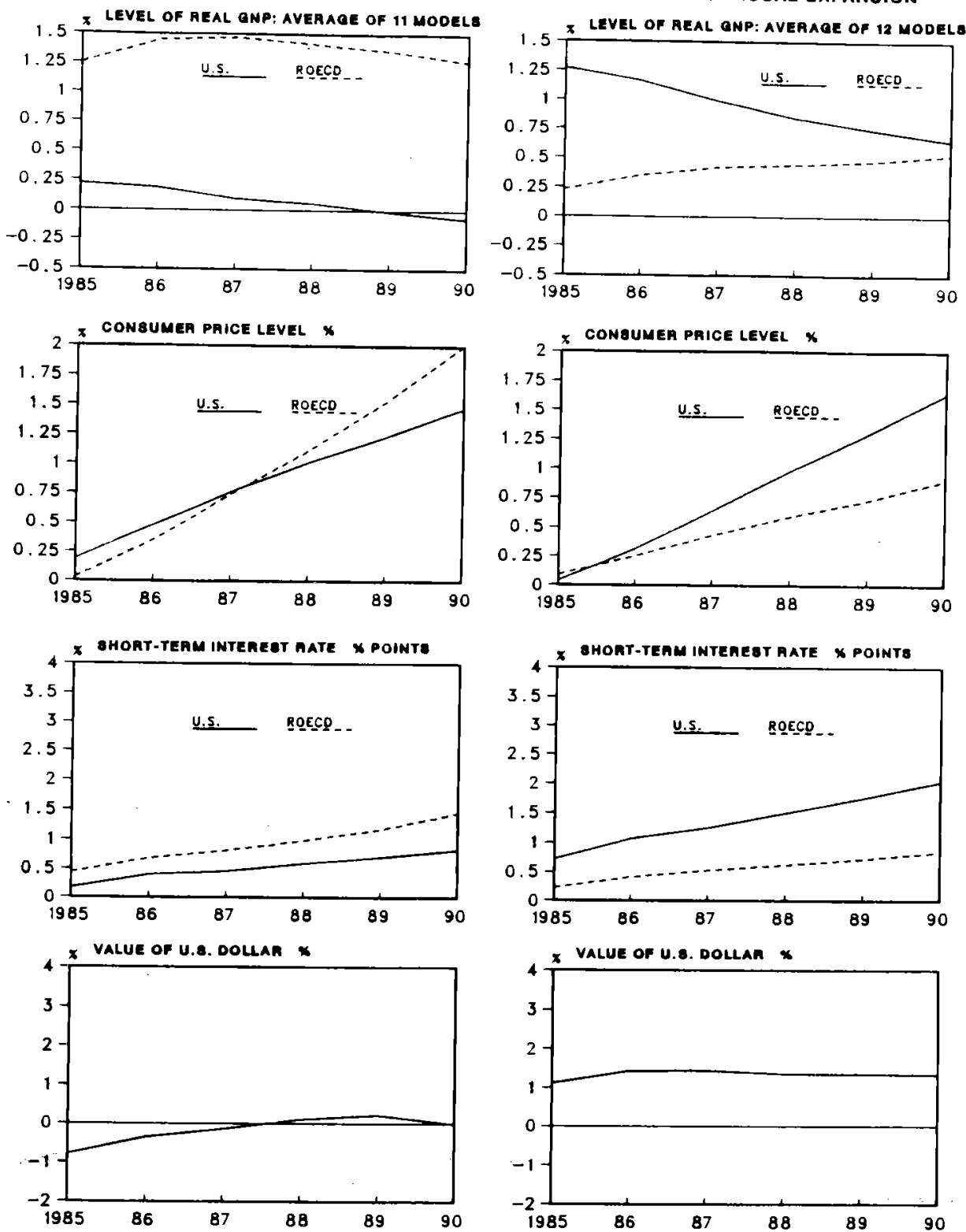
FIGUKE 2

\section{U.S. CURAENT BALANCE EFFECTS OF U.S. FISCAL EXPANSION}
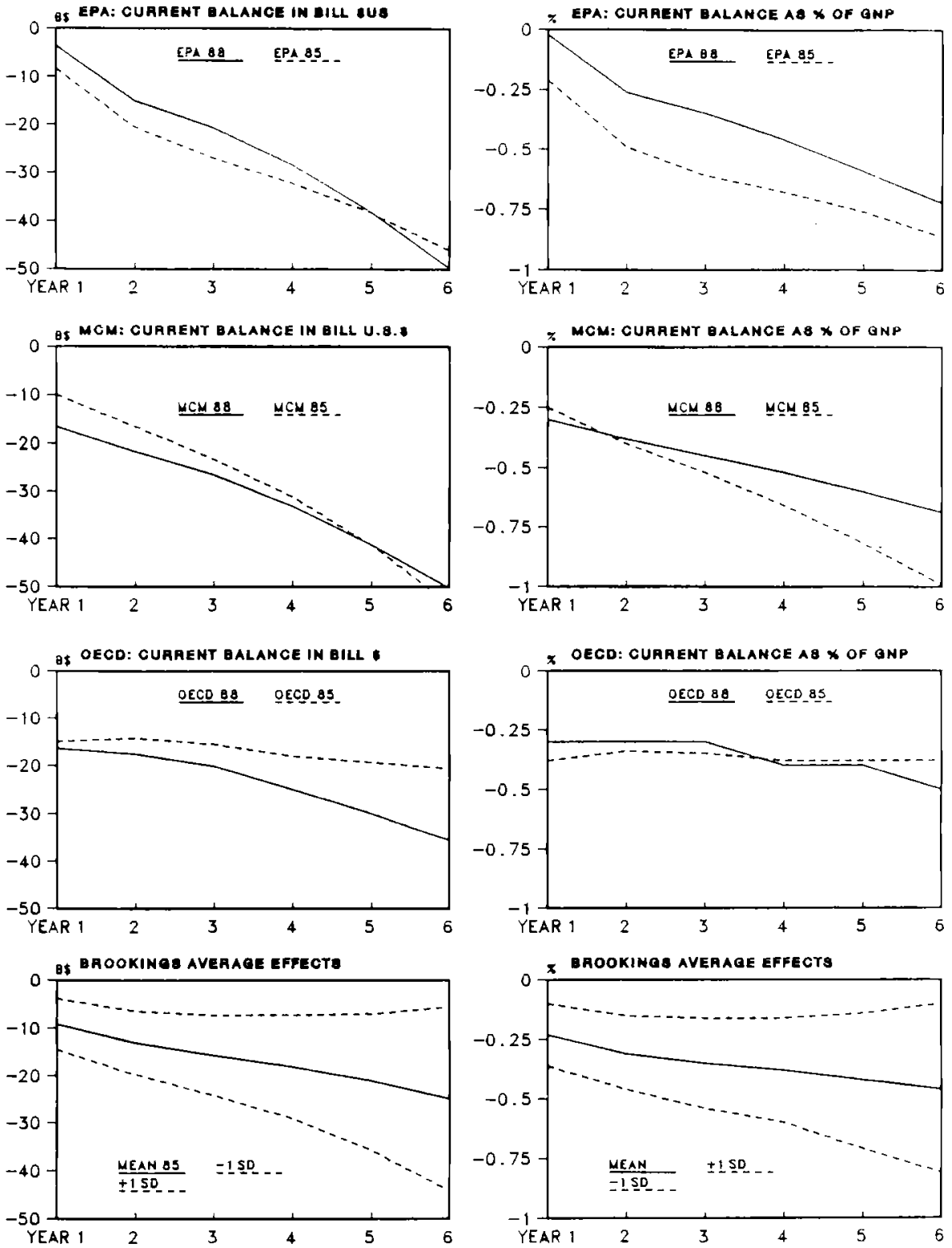


\section{FIGURE 3}

JAPANESE CURRENT BALANCE EFFECTS OF FISCAL EXPANSIONS
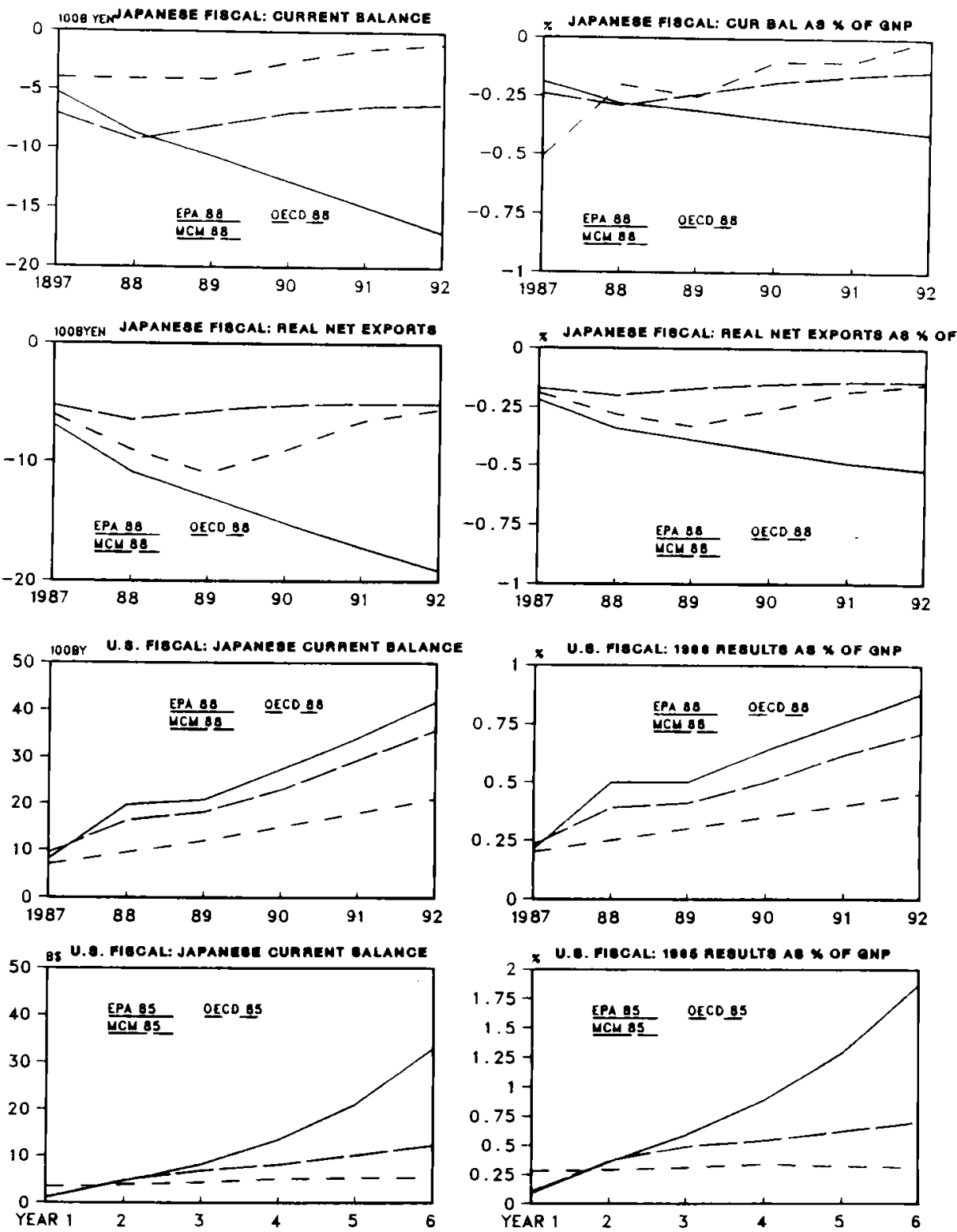


\section{FIGURE 4}

\section{OWN-COUNTRY EFFECTS OF FISCAL EXPANSION}
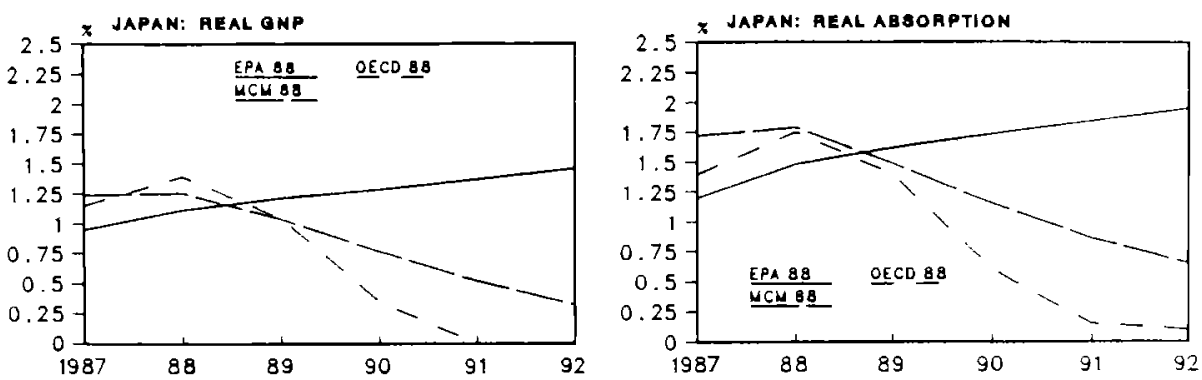

* JAPAN: GROBe pAIVATE savinge as * OF ONP
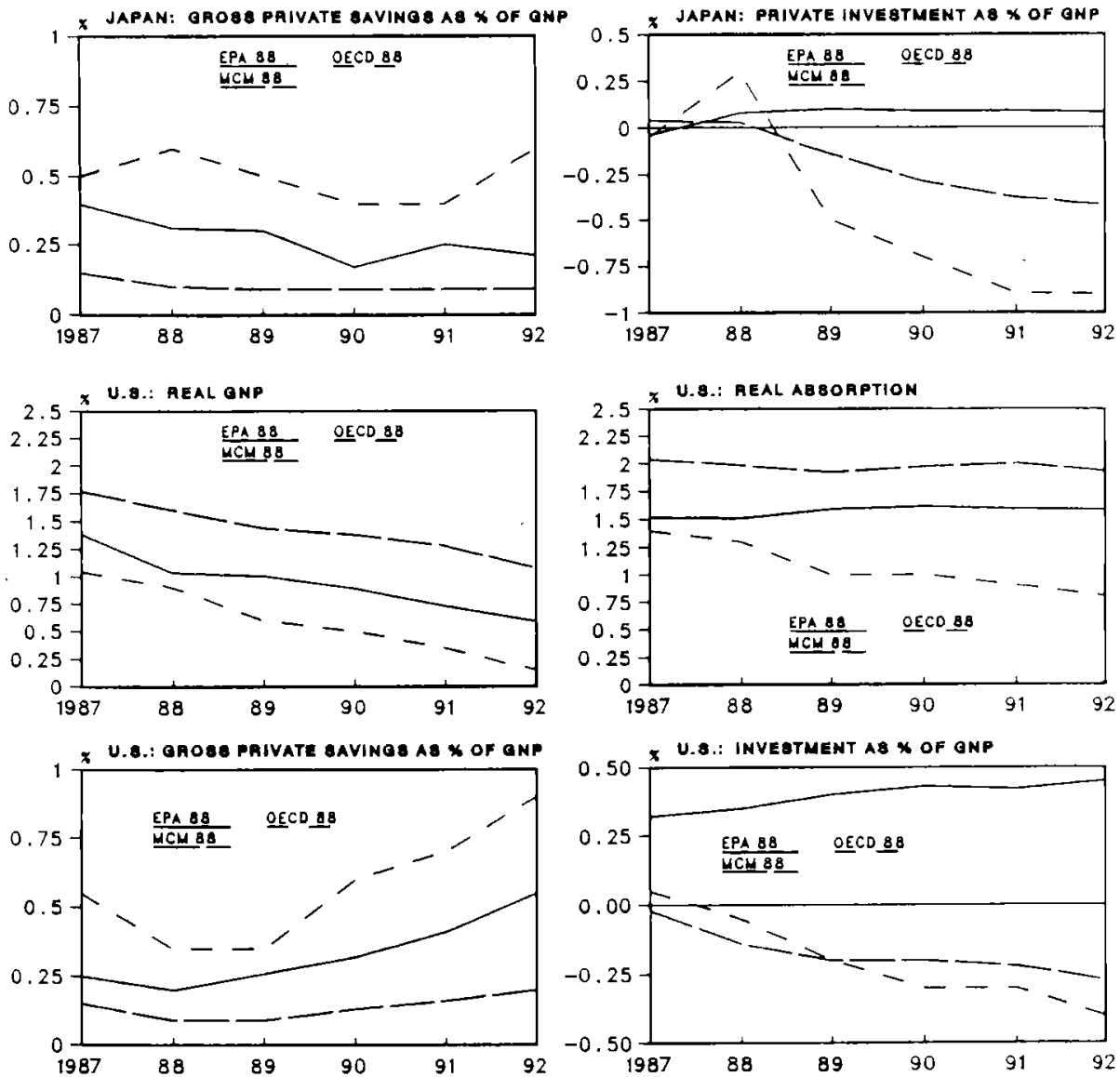


\section{FIGURE 5}

JAPANESE FISCAL EXPANSION
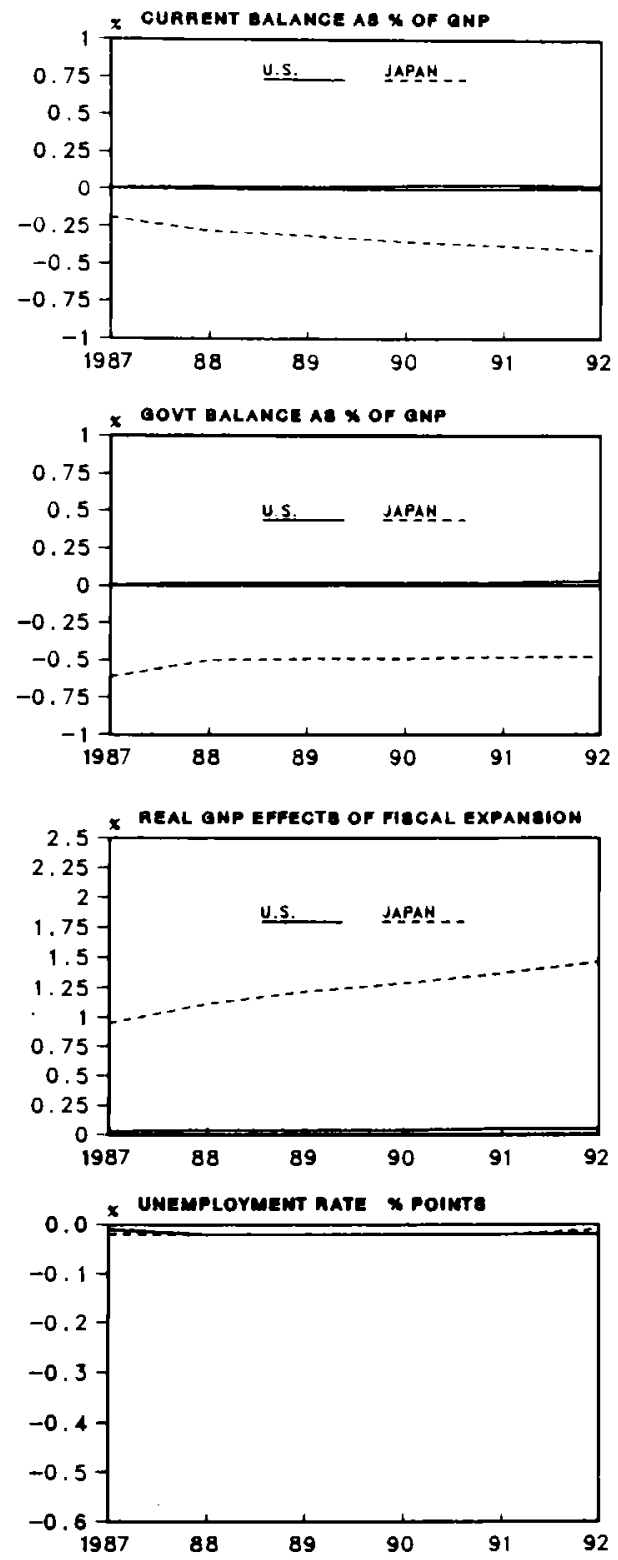

U.s. FISCAL EXPANSION
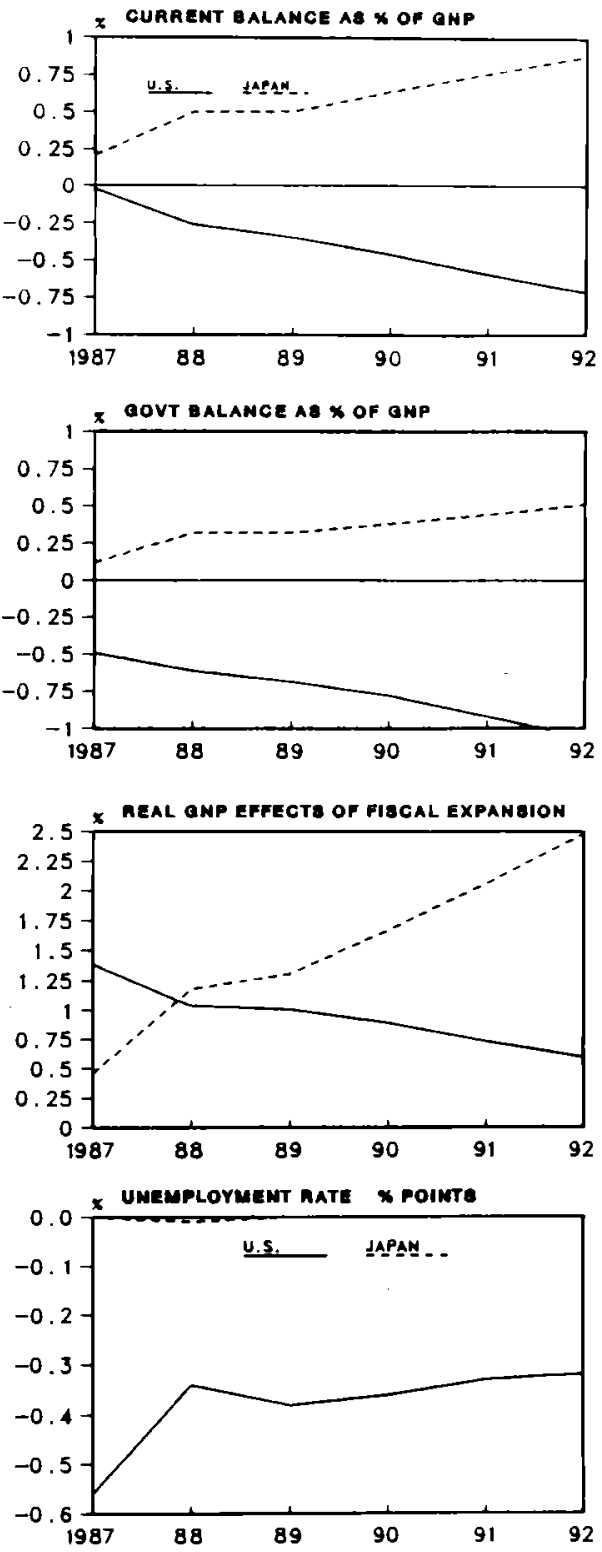


\section{FIGCRE 6}

JAPANESE FISCAL EXPANSION
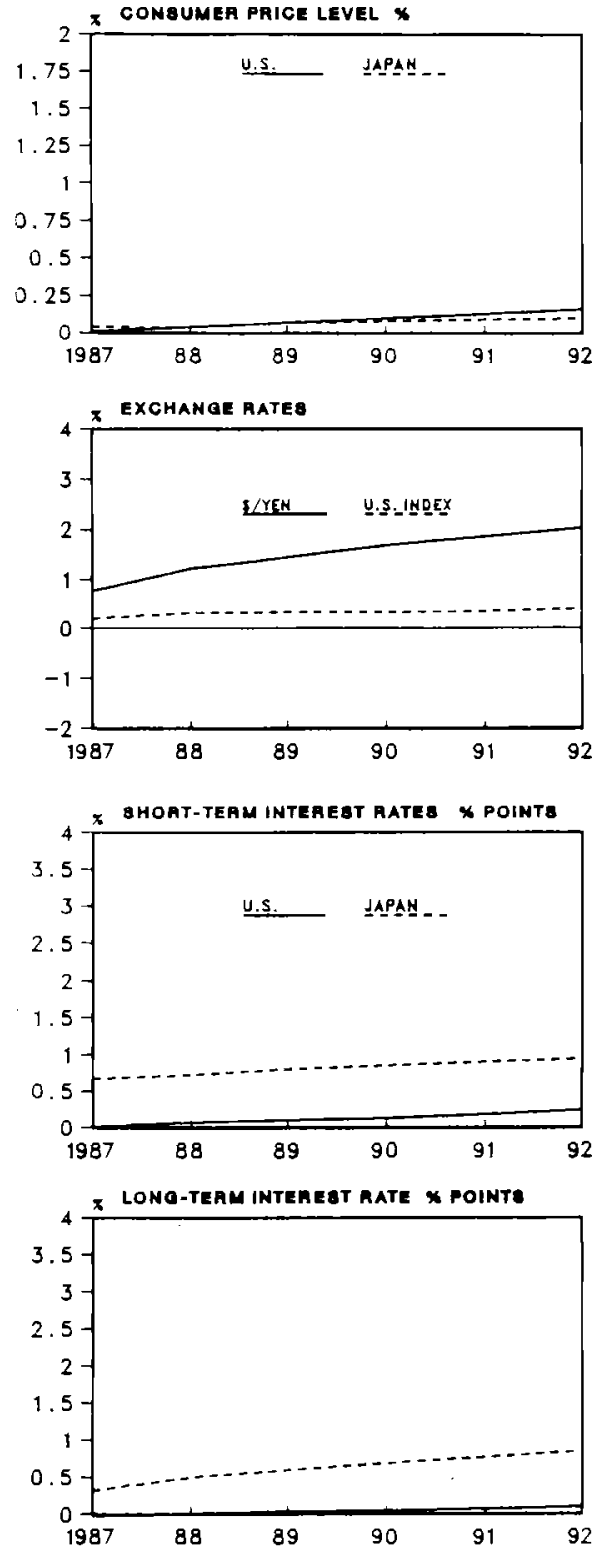

EPA

U.3. FISCAL EXPANSION
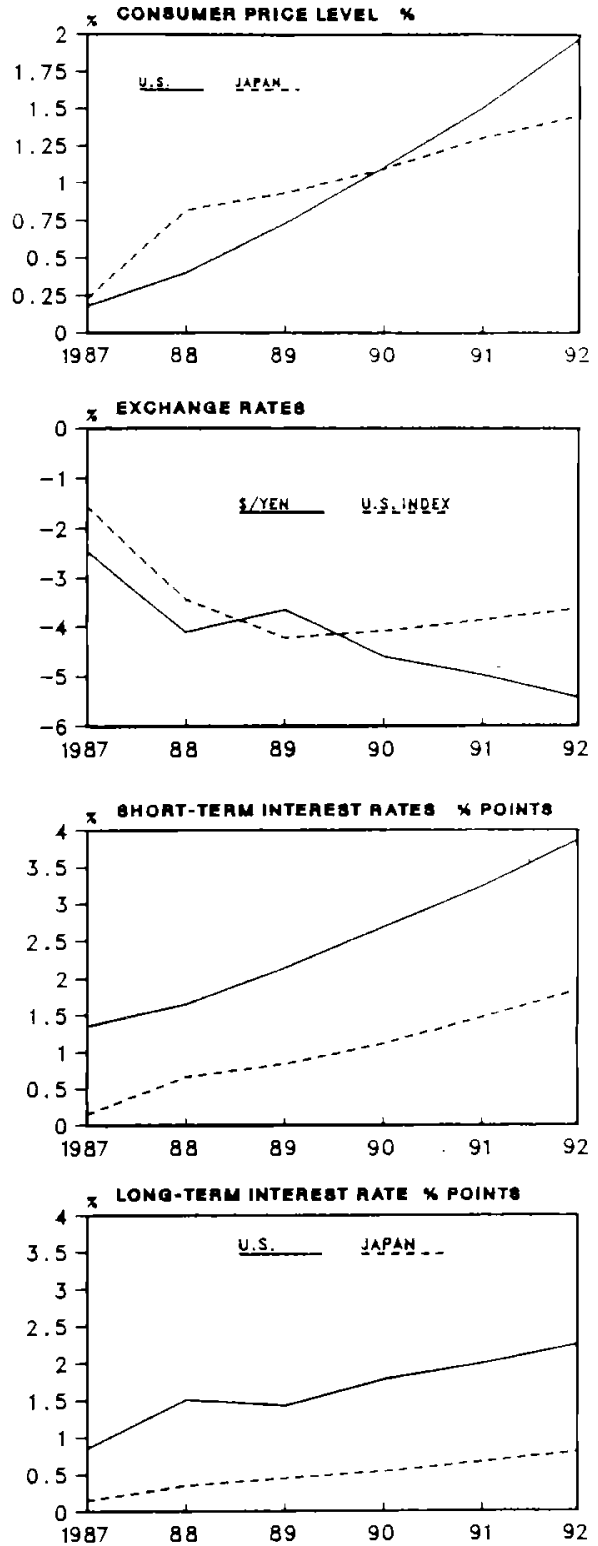


\section{FIGURE 7}

japanese fiscal expansion MCM
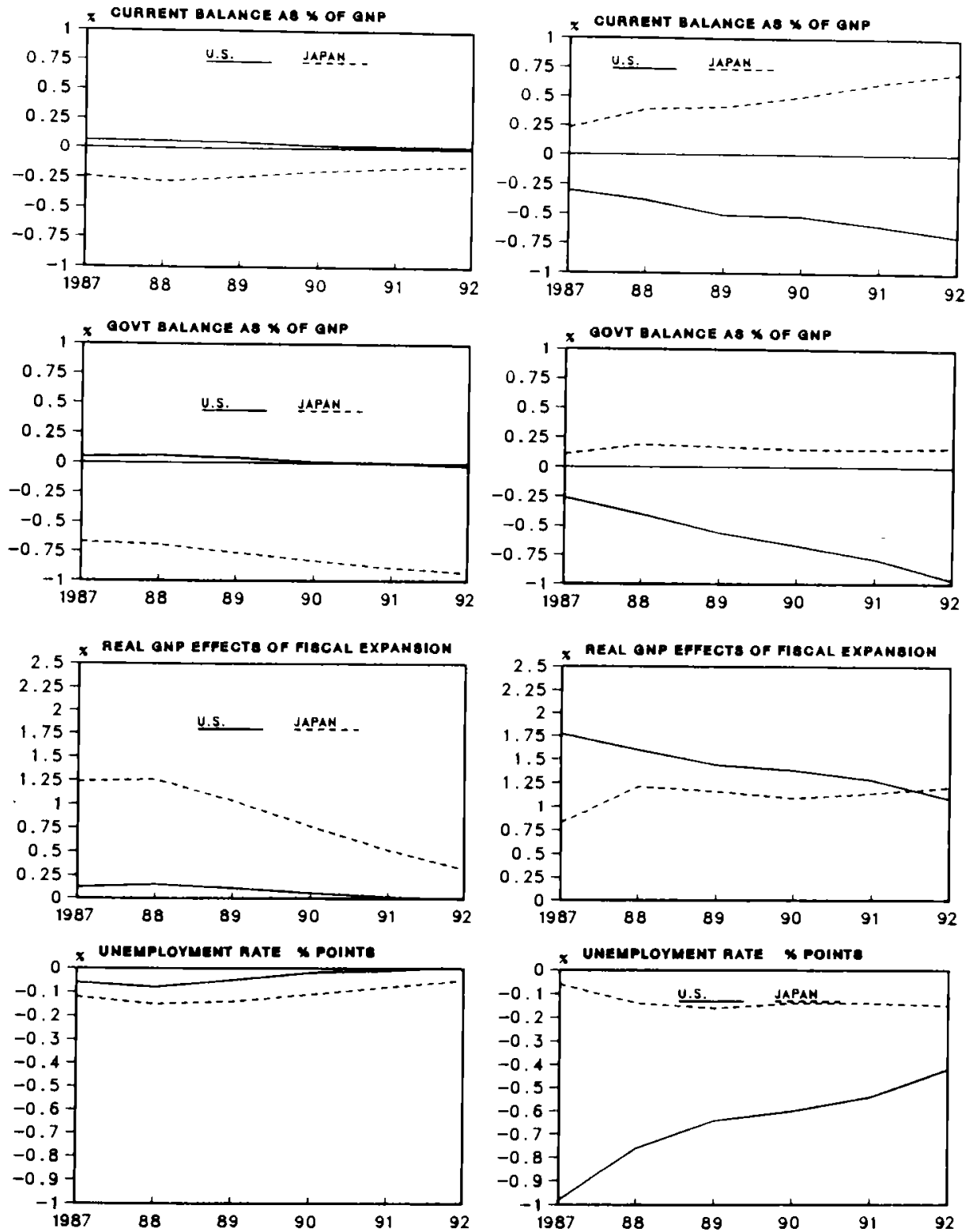
FIGURE \&

JAPANESE FISCAL EXPANSION

\section{MCM}

U.3. FISCAL EXPANSION
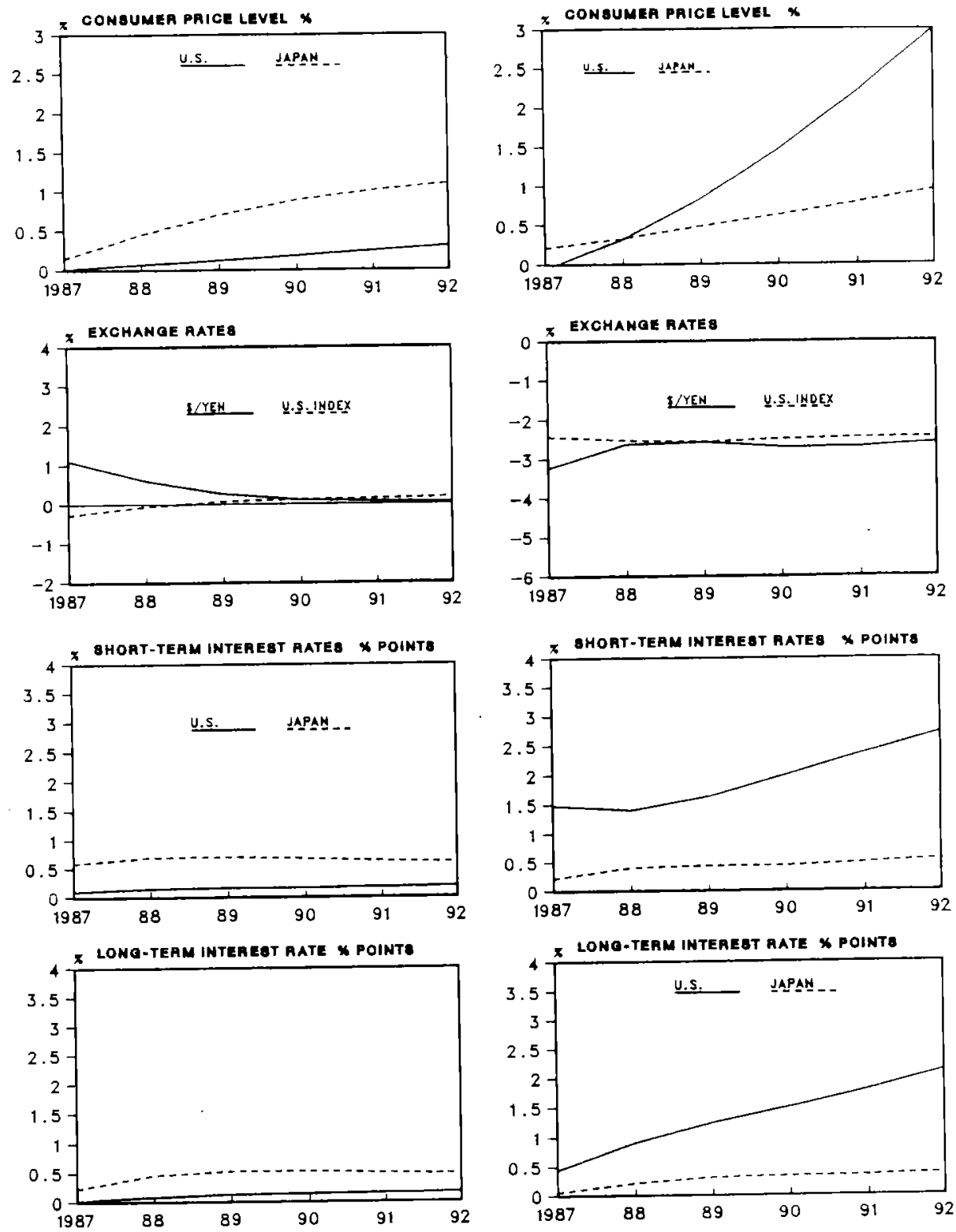


\section{HGUKE Y}

JAPANESE FISCAL EXPANSION
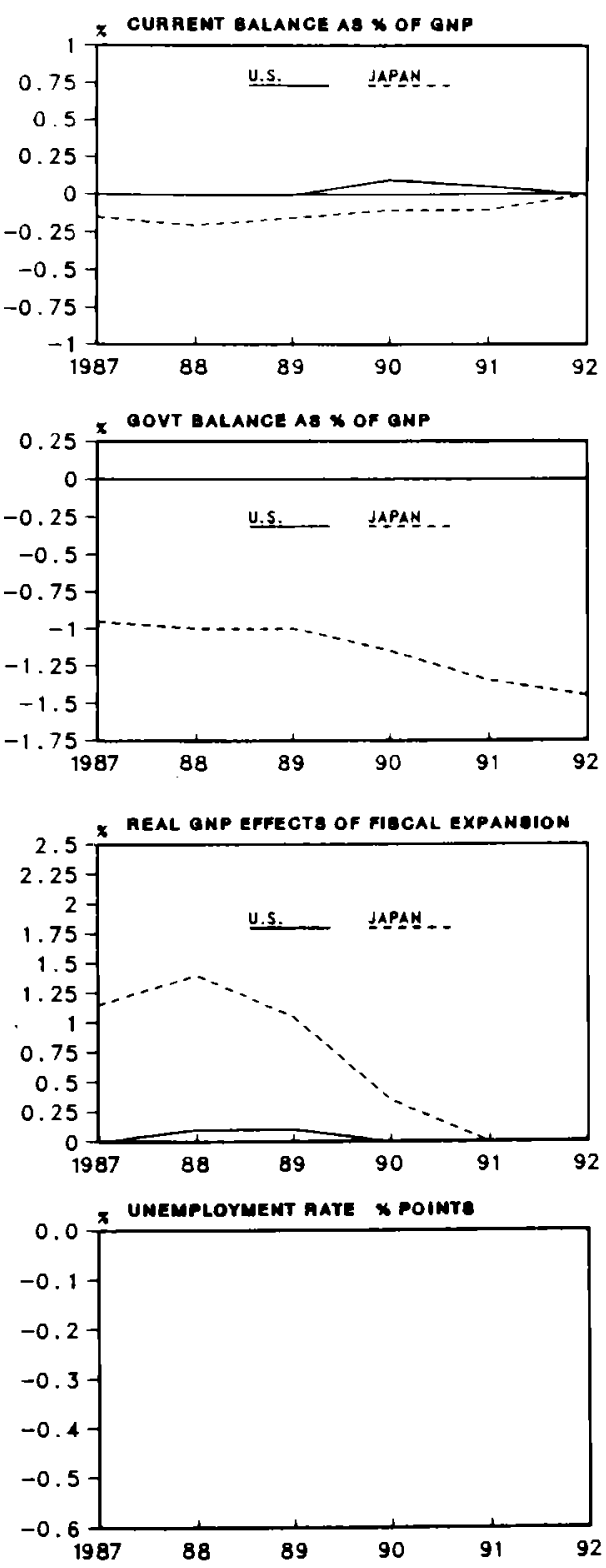

\section{OECD}

U.8. FISCAL EXPANSION
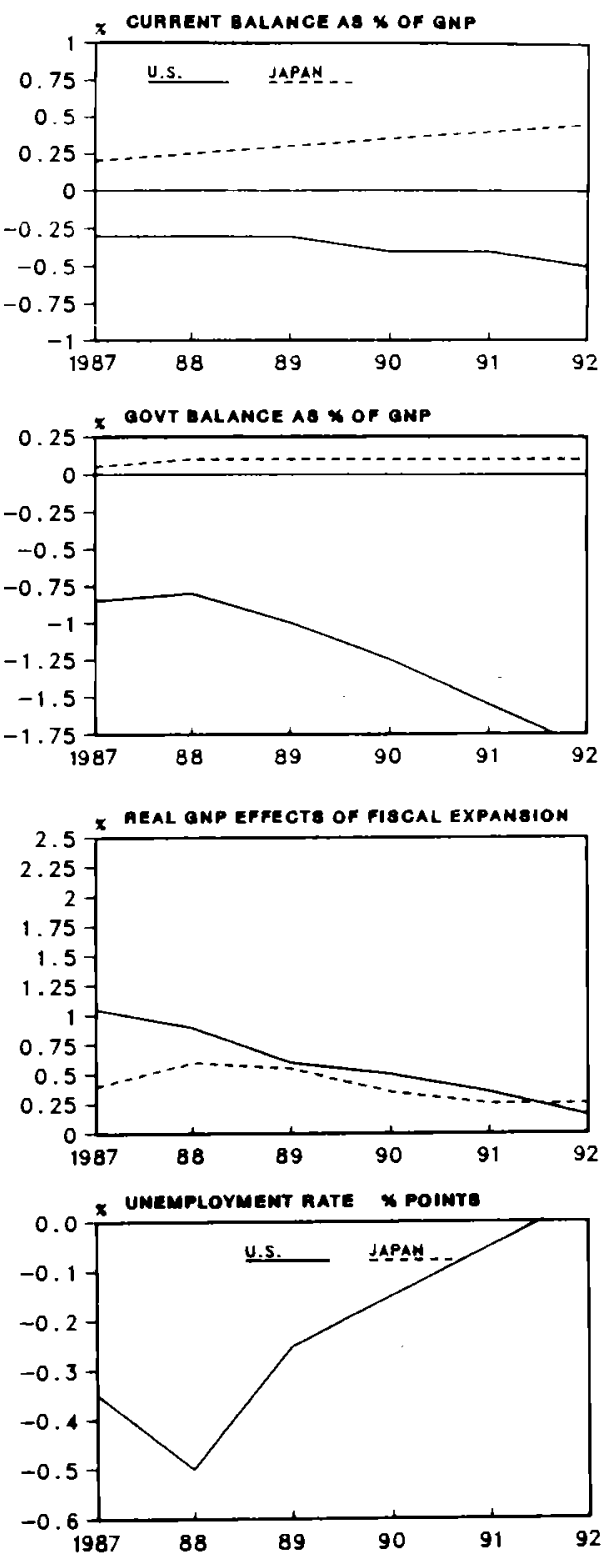


\section{FIGURE 10}

JAPANESE FISGAL EXPANsion OECD

U.S. FISCAL EXPANSION
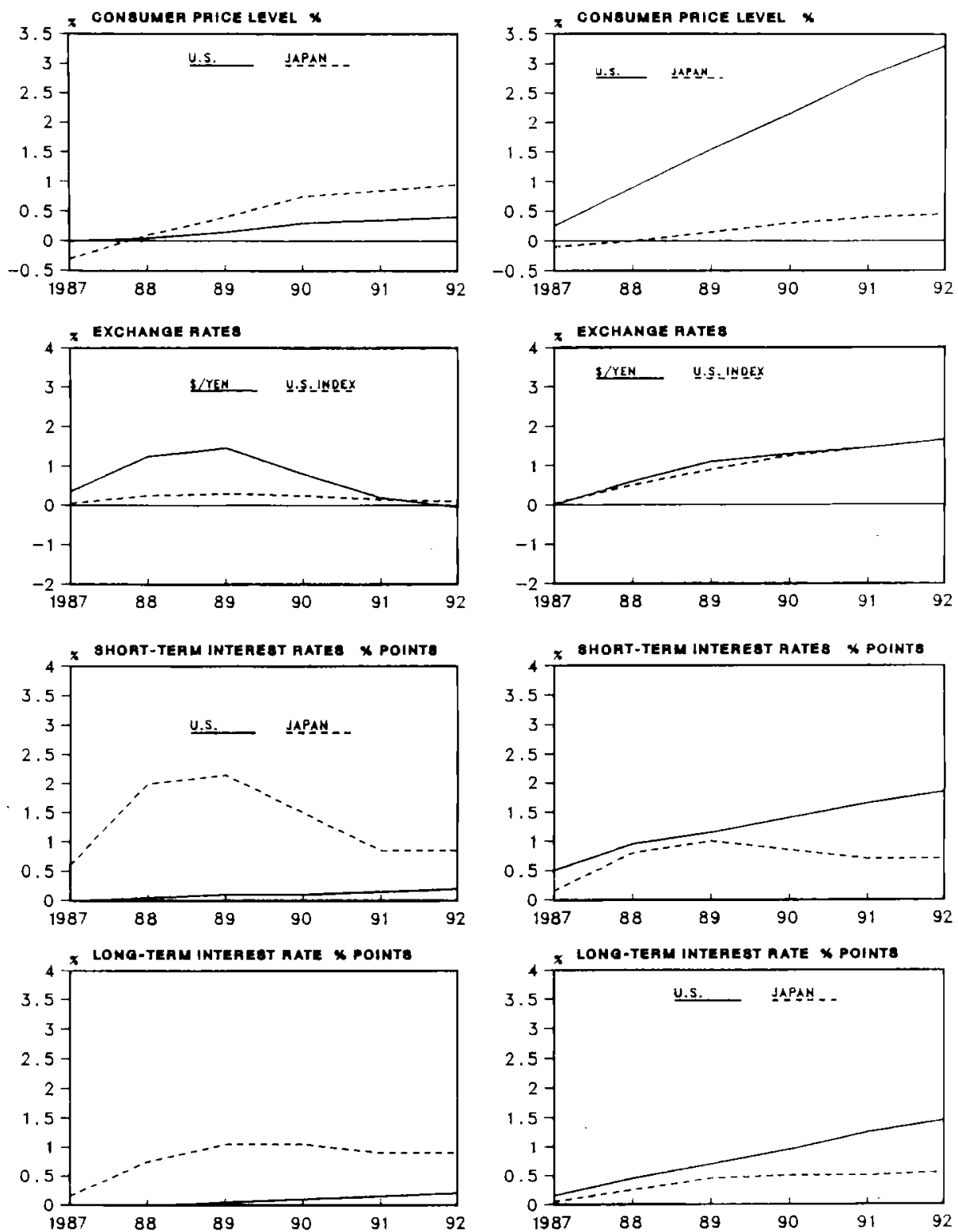
FIUUKE 11

ROLE OF EXCHANGE RATES IN FISCAL TRANSMISSION
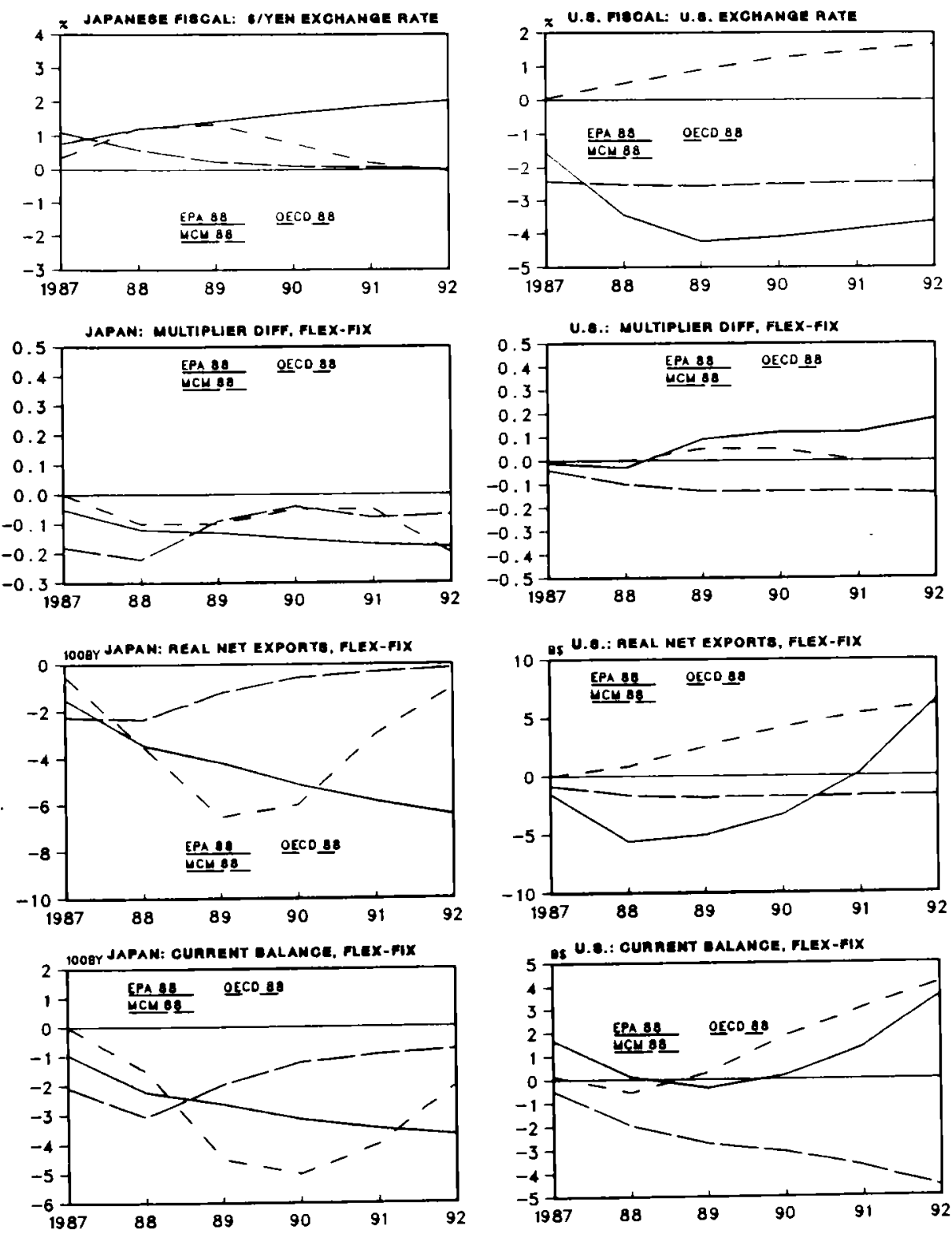
HIGUKE IL

PARTIAL VS FULL MODEL EFFECTS OF EXCHANGE RATES
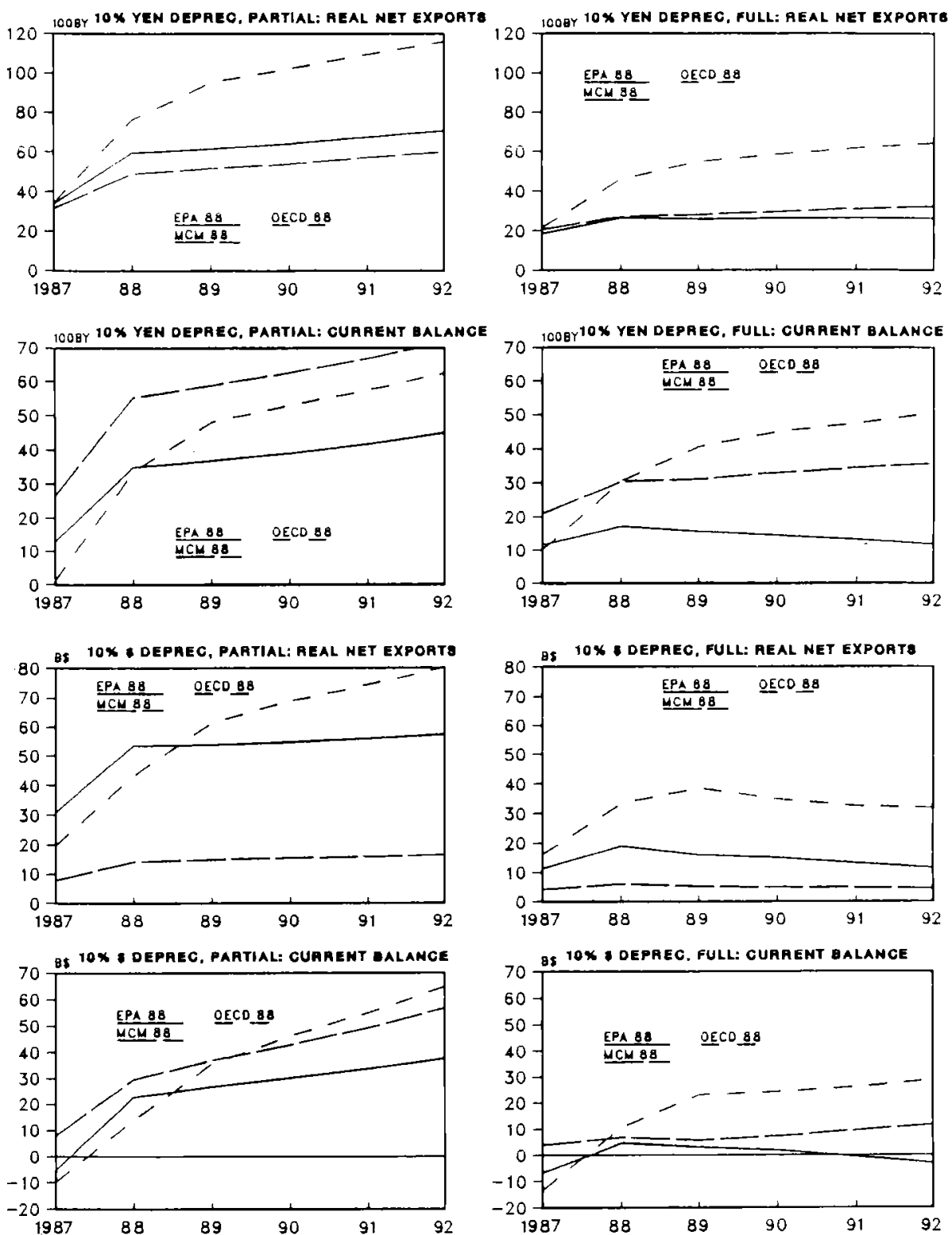